INSTITUTO DE PESQUISAS ENERGÉTICAS E NUCLEARES

Autarquia associada à Universidade de São Paulo

\title{
ESTUDO DO USO DA RADIAÇÃO IONIZANTE COMO FERRAMENTA DE SELEÇÃO DE FORMAS PROMASTIGOTAS METACÍCLICAS DE Leishmania amazonensis, E A INDUÇÃO DE RESPOSTA IMUNOLÓGICA EM MODELOS EXPERIMENTAIS.
}

FRANCO CLAUDIO BONETTI

Tese apresentada como parte dos requisitos para obtenção do Grau de Doutor em Ciências na área de Tecnologia Nuclear- Aplicações

Orientadora: Dra. Nanci do Nascimento 
"Omne vivum ex vivo"

(Um ser vivo sempre provém de outro ser vivo)

William Harvey 
Ao meu filho lan e à minha eterna namorada, Andréa Sanchez. 
À minha mãe pela torcida. 
Ao meu pai e à Meire pelo incentivo. 


\section{AGRADECIMENTOS}

À minha orientadora Profa. Dra. Nanci do Nascimento por me guiar ao longo de mais este trabalho e nunca negar apoio às minhas idéias.

Ao Prof. Dr. Heitor Franco de Andrade Jr., por me proporcionar mais esta oportunidade, e ceder espaço no Laboratório de Protozoologia da FMUSP, além de sua irrestrita colaboração para o bom andamento do trabalho.

Ao Andrés Jimenez Galisteo Jr., por seu otimismo e confiança nos bons resultados, ao longo de todo trabalho.

Ao Daniel Perez Vieira, por seu bom humor diário, sempre solicito.

À Byanca Paiva pelo auxílio nas técnicas de Biologia Molecular.

À Janaina Alves Baptista pela amizade e pelo auxilio com os ensaios com Imunoglobulinas.

À Neide pela manutenção dos animais imunodeficientes.

À Roselaine Pereira Alvim Cardoso pelo auxílio técnico, pela amizade e pelas festas.

À Dna. Francisca pelo cafezinho, pelas boas risadas e manutenção da ordem e dos bons costumes nos momentos de euforia coletiva.

À Solange Fernandes Ferreira dos Santos, pela burocracia envolvida.

Ao Luciano Monteiro da Silva, por fazer o laboratório funcionar.

À todos os amigos do Instituto de Medicina Tropical da Faculdade de Medicina da USP, pelo companheirismo.

À todos os amigos da Divisão de Radiobiologia do Instituto de Pesquisas Energéticas e Nucleares - IPEN - pela amizade.

À todas as outras pessoas que apesar de não estarem aqui relacionados certamente serão sempre lembrados por sua colaboração.

Ao LIM49FMUSP e a Supervisão de Radiobiologia/IPEN pelo suporte ao projeto.

À CAPES pelo suporte financeiro ao projeto. 


\title{
ESTUDO DO USO DA RADIAÇÃO IONIZANTE COMO FERRAMENTA DE SELEÇÃO DE FORMAS PROMASTIGOTAS METACÍCLICAS DE Leishmania amazonensis, E A INDUÇÃO DE RESPOSTA IMUNOLÓGICA EM MODELOS EXPERIMENTAIS.
}

\author{
Franco Claudio Bonetti
}

\begin{abstract}
RESUMO
Atualmente, milhões de pessoas, por todo o globo, estão sob risco de serem infectados por um protozoário transmitido vetorialmente por pequenos insetos flebotomíneos. Este parasita é a Leishmania spp., causadora de uma patologia de amplo espectro, que varia desde a moléstia cutânea (tegumentar) até a visceral (kala-azar). A leishmaniose cutânea é a manifestação clínica de maior ocorrência (mais de $90 \%$ dos casos). A radiação ionizante, gerada em fonte de ${ }^{60} \mathrm{Co}$, tem sido utilizada com sucesso para promover alterações físico-químicas em diferentes protozoários, incluindo a Leishmania spp. Em trabalhos anteriores determinou-se que formas promastigotas de Leishmania amazonensis, irradiadas com diferentes doses de radiação gama, perdem sua viabilidade mantendo, porém, sua imunogenicidade. No presente trabalho, estudouse a utilização da radiação ionizante como ferramenta na seleção de formas metacíclicas do parasita em cultura axênica para a possível produção de imunógenos irradiados mais eficientes. Os resultados demonstram que culturas irradiadas com 400 Gy de radiação gama, possuem uma concentração de aproximadamente $75 \%$ de parasitas metacíclicos, capazes de produzir, in vitro, uma infecção que mimetiza a ocorrida naturalmente. Estes parasitas irradiados têm sua estrutura celular interna modificada mantendo, entretanto, seu arcabouço externo intacto. Camundongos de uma linhagem suscetível imunizados com leishmanias irradiadas com diferentes doses tiveram sua produção de imunoglobulinas aumentada, e mantiveram os títulos elevados após o desafio com parasitas não irradiados. Em outras linhagens pesquisadas este padrão se manteve, porém em títulos menores, sendo que camundongos imunodeficientes não responderam à imunização nem ao desafio.
\end{abstract}




\author{
THE STUDY OF IONIZING RADIATION AS A TOOL FOR SELECT PROMASTIGOTES \\ FORMS OF LEISHMANIA AMAZONENSIS, AND THE IMMUNOLOGICAL RESPONSE \\ IN EXPERIMENTAL MODELS. \\ Franco Claudio Bonetti
}

\begin{abstract}
Actually, millions of people around the globe are under the risk of infection by a protozoan transmitted by a bit of a sand fly. This parasite is a Leishmania spp. This causes a wide spectrum disease, since a coetaneous disease to a visceral one. The coetaneous form is the major clinical manifestation (above 90\%). The ionizing radiation, produced in a ${ }^{60} \mathrm{Co}$ font, had being successes used to promote physical-chemical transformations on different protozoans, including Leishmania spp. In previous work was determined that promastigotes forms of Leishmania amazonensis, irradiated with different doses of radiation, lost their viability maintaining, however, their immunogenicity. In this work, was studied the use of ionizing radiation as a tool for selection of metaciclic forms of the parasite in axenic culture, for a possible efficient irradiated immunogen production. Our results shown that cultures irradiated with 400 Gy of gamma irradiation, has $75 \%$ of metaciclic form, which are capable to produce, in vitro, an infection that is similar the natural occurrence. These irradiated parasites have their internal cellular structure modified, maintaining their external structure intact. Susceptible strain of mice immunized with leishmania irradiated with different doses had high immunoglobulin production, and maintained this production after the challenge with naive parasites. In other strains this default was similar, however in lower titles. Immunodeficient mice didn't produce immunoglobulin nor on the immunization or on the challenge.
\end{abstract}




\section{SUMÁRIO}

RESUMO.

ABSTRACT

SUMÁRIO IX

LISTA DE FIGURAS. XII

1. INTRODUÇÃO. 1

1.1. Considerações Gerais e Breve Resumo Histórico ............................................1

1.2. Morfologia e Metabolismo Celular...............................................................

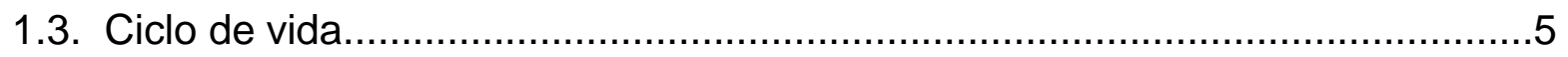

1.4. Dinâmica da infecção e Resposta Imune envolvida..........................................7

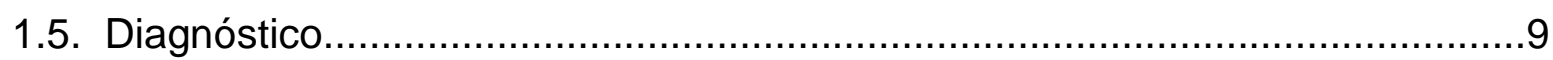

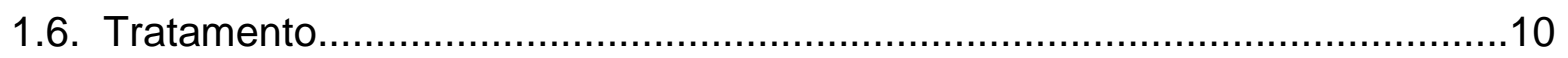

1.7. A Radiação lonizante............................................................................11

2. OBJETIVOS

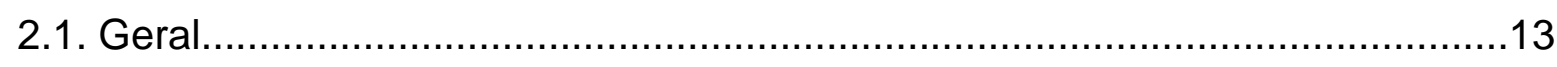

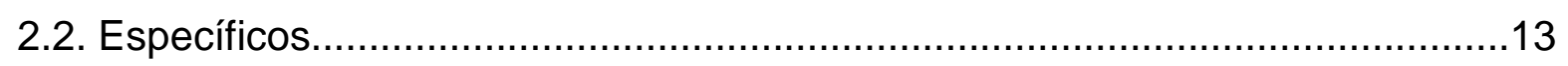

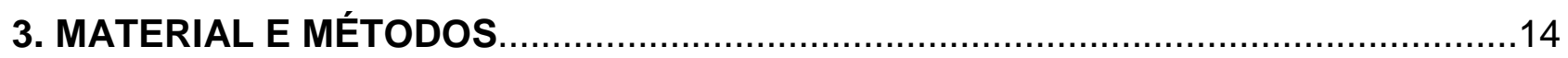

3.1. Cultivo de células RAW.........................................................................14

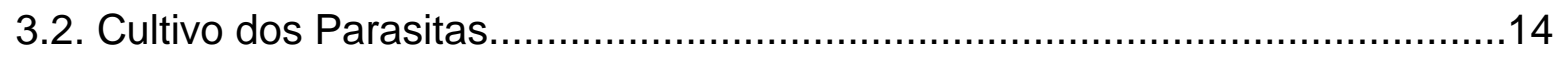

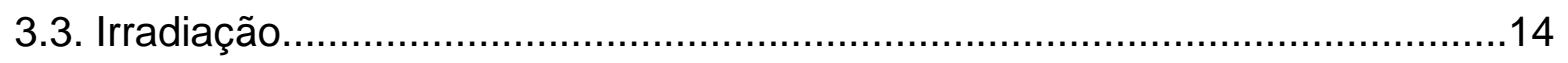

3.4. Ensaio de fixação de complemento...........................................................15 
3.5. Ensaios para determinação do tempo médio de metaciclogênese de Leishmania amazonensis in vitro .................................................................15

3.6. Ensaios de infecção de células RAW in vitro ................................................15

3.7. Microscopia eletrônica............................................................................

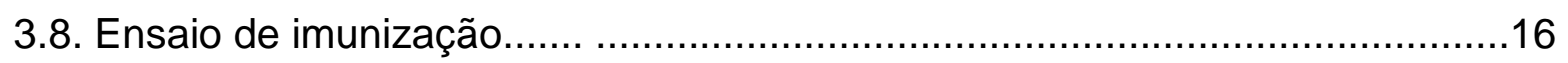

3.9. Ensaios Imunoenzimáticos (Enzyme Linked Immunossorbent Assay -

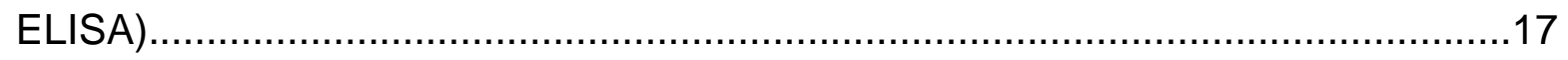

3.10. Sub-classes de Imunoglobulinas..........................................................17

3.11. Reação em cadeia da Polimerase (PCR) .................................................18

3.11.1 Extração das amostras....................................................................18

3.11.2. Preparação da mix........................................................................18

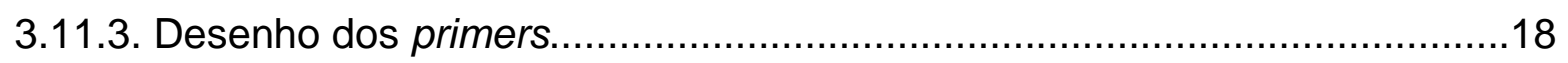

3.11.4. Amplificação do material.....................................................................18

3.11.5. Eletroforese

3.12. Análises estatísticas.........................................................................19

4. RESULTADOS

4.1. Ensaios para determinação do tempo médio de metaciclogênese de

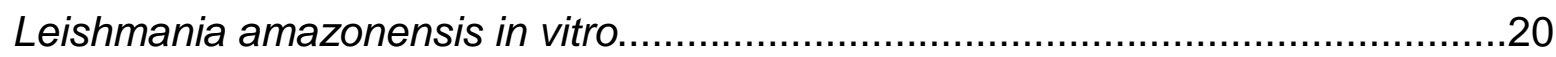

4.2. Ensaios de infecção de células RAW in vitro...............................................21

4.3. Ensaio de fixação de complemento.............................................................23

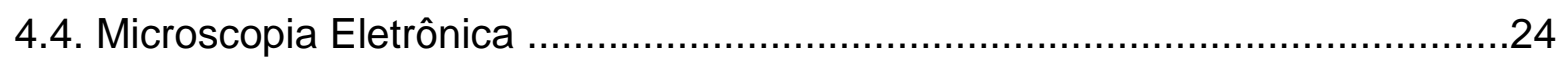

4.5. Ensaios de Imunização de modelos experimentais........................................26

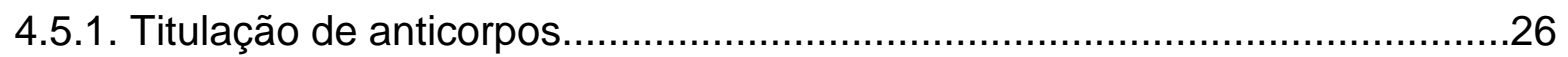




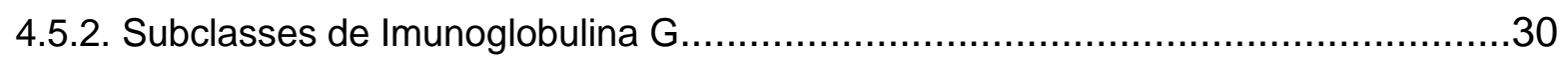

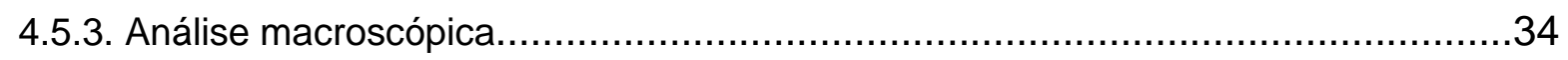

4.5.4. Reação em Cadeia da Polimerase (PCR) ...........................................

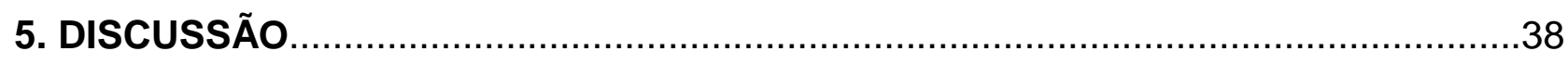

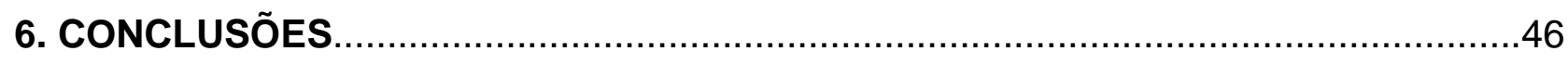

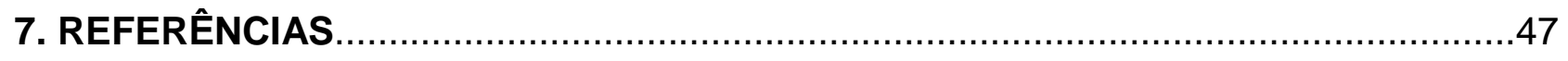

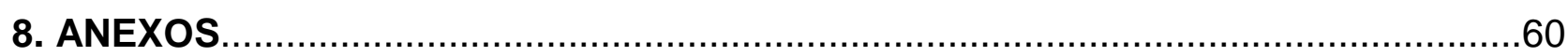

8.1. Artigo - INAC 2005 - FRANCO C. BONETTI, HEITOR FRANCO DE ANDRADE JR. AND NANCI DO NASCIMENTO Metacyclic promastigotes of Leishmania amazonensis selection using gamma irradiation. International Nuclear Atlantic Conference, Santos, SP, Brazil, August 28 to September 2, 2005. 


\section{LISTA DE FIGURAS}

Figura 1: Microscopia eletrônica de forma promastigota de Leishmania amazonensis. .5

Figura 2: Ciclo de vida da Leishmania spp.

Figura 3: Concentração do número de formas promastigotas de Leishmania amazonensis por ml, cultivadas em meio RPMI durante 7 dias. 20

Figura 4. Concentração de Leishmania amazonensis, mantida em meio HBSS, submetidas à irradiação com diferentes doses de raios gama: 25, 50, 100, 200 e 400 Gy...... .21

Figura 5: Porcentagem de células RAW infectadas com formas promastigotas de Leishmania amazonensis irradiadas com diferentes doses de: 25, 50, 100, 200 e 400 Gy de radiação gama $\left({ }^{60} \mathrm{Co}\right)$... 22

Figura 6: Porcentagem de sobrevivência das formas promastigotas de Leishmania amazonensis, em meio de cultura HBSS, irradiadas com doses de 25, 50, 100, 200 e 400 Gy de radiação gama, incubadas com diferentes concentrações de soro de cobaio. .23

Figura 7: Fotos de Microscopia Eletrônica de formas promastigotas de Leishmania amazonensis, irradiados ou não, e submetidos, ou não, à incubação com soro de cobaio não inativado, para interação com moléculas do Sistema Complemento. 24

Figura 8: Densidade óptica dos títulos de anticorpos produzidos por camundongos Balb/c, no dia zero (primeira dose de imunização), dia 45 (desafio) e dia 90 (45 dias após a infecção)..... 26

Figura 9: Densidade óptica dos títulos de anticorpos produzidos por camundongos c57/bl, no dia zero (primeira dose de imunização), dia 45 (desafio) e dia 90 (45 dias após a infecção)..... 27

Figura 10: Densidade óptica dos títulos de anticorpos produzidos por camundongos Balb/c ${ }^{\text {nu/nu }}$ no dia zero (primeira dose de imunização), dia 45 (desafio) e dia 90 (45 dias após a infecção) 28

Figura 11: Densidade óptica dos títulos de anticorpos produzidos por camundongos Balb/c $\mathrm{c}^{\text {scid }}$, no dia zero (primeira dose de imunização), dia 45 (desafio) e dia 90 (45 dias após a infecção). .29

Figura 12: Densidade óptica dos títulos de três diferentes subclasses de Imunoglobulina G $(\operatorname{lgG} 1$, $\lg$ (a e e $\operatorname{lgG} 2 b$ ) produzidos por camundongos Balb/c no dia zero (primeira dose de imunização), dia 45 (desafio) e dia 90 (45 dias após a infecção) 30

Figura 13: Densidade óptica dos títulos de três diferentes subclasses de Imunoglobulina G (IgG 1, $\lg$ 2a e $\lg G 2 b$ ) produzidos por camundongos c57/bl no dia zero (primeira dose de imunização), dia 45 (desafio) e dia 90 (45 dias após a infecção).

Figura 14: Densidade óptica dos títulos de três diferentes subclasses de Imunoglobulina G ( $\operatorname{lgG} 1$, IgG 2a e IgG 2b) produzidos por camundongos Balb/c nunu no dia zero (primeira dose de imunização), dia 45 (desafio) e dia 90 (45 dias após a infecção)...... 32 
Figura 15: Densidade óptica dos títulos de três diferentes subclasses de Imunoglobulina G ( $\lg$ G 1 , $\lg$ 2a e $\lg$ 2b) produzidos por camundongos Balb/c $\mathrm{c}^{\text {scid }}$ no dia zero (primeira dose de imunização), dia 45 (desafio) e dia 90 (45 dias após a infecção)......

Figura 16: Espessura das patas traseiras de camundongos Balb/c, no dia do desafio com formas viáveis de promastigotas de $L$. amazonensis e 45 dias após a infecção 34

Figura 17: Espessura das patas traseiras de camundongos c57/bl, no dia do desafio com formas viáveis de promastigotas de $L$. amazonensis e 45 dias após a infecção 35

Figura 18: Espessura das patas traseiras de camundongos Balb/c $\mathrm{c}^{\text {nu/nu}}$, no dia do desafio com formas viáveis de promastigotas de L. amazonensis e 45 dias após a infecção 35

Figura 19: Espessura das patas traseiras de camundongos Balb/c $\mathrm{c}^{\text {scid }}$, no dia do desafio com formas viáveis de promastigotas de $L$. amazonensis e 45 dias após a infecção.

Figura 20: Eletroforese em gel de agarose de uma reação de Polimerase Chain Reaction (PCR), apresentando banda para caracterização de material genético ribossomal de protozoários do Gênero Leishmania spp., de 520 pares de base (520 bp)... 


\section{INTRODUÇÃO}

\subsection{Considerações Gerais e Resumo Histórico}

As doenças infecciosas acompanham a humanidade desde o seu surgimento, com os primeiros hominídeos, em torno de 4 milhões de anos atrás. Os primeiros microorganismos surgiram em um passado bem mais remoto, há cerca de 3,5 bilhões de anos, antes mesmo do início do acúmulo de Oxigênio na atmosfera, por conta da existência de uma substância primordial formada puramente de aminoácidos organizados aleatoriamente, sob a pressão seletiva de uma atmosfera redutora, e facilitação pela elevada temperatura dos oceanos daquela Era, segundo uma das Teorias mais aceitas sobre a Biogênese e a origem da vida em nosso Planeta (OPARIN, 1976; HALDANE, 1928).

Milhares de anos depois, surgem as células eucariontes, com uma formação mais complexa, envoltório nuclear e a presença de organelas membranosas, inexistentes nos procariontes até então. E em torno de 1,4 Bilhões de anos surgem, provavelmente, os primeiros protozoários: organismos unicelulares, eucariontes bastante complexos, com sistemas reprodutor, digestivo, de locomoção e de produção de energia; relacionados desta forma segundo a cladística proposta por Willi Hennig, em sua obra Grundzüge einer Theorie der Phylogenetischen Systematik (1950). O presente trabalho tem como base 0 estudo de um dos 8 mil protozoários parasitas conhecidos na atualidade.

Reino: Protista, Filo: Protozoa, Sub-Filo: Sarcomastigophora, Classe: Mastigophora, Ordem: Kinetoplastida, Família: Trypanosomatidae, Gênero: Leishmania (COURA, 2005).

Descrito pela primeira vez em 1903 pelo médico escocês Willian Leishman, durante uma incursão do exército Britânico na Índia, e meses depois, por Charles Donovan, com relatos parecidos, este microorganismo passou então a ser denominado corpos de Leishman-Donovan. Alguns anos depois o Prêmio Nobel de Medicina de 1902, Ronald Ross, sugere o nome Leishmania donovani, em homenagem aos pesquisadores que 0 descreveram. No Brasil, o parasita foi descrito no início do Século XX por Lindemberg em 1909 e posteriormente por Rabello em 1910, sendo dado o nome de "Úlcera de Bauru" ao conjunto de sinais cutâneos e sintomas clínicos acarretados pela enfermidade. Em 1911, Gaspar Vianna propõe o nome Leishmania brasiliensis, para os parasitos ocorridos no Brasil, por serem morfologicamente diferentes daqueles causadores do "Botão do Oriente" 
asiático (ALTAMIRANO-ENCISO et al., 2003; VALE \& FURTADO, 2005).

Atualmente, cerca de 12 milhões de pessoas estão infectadas e outras 500 milhões, distribuídas em 88 países, estão sob risco de serem contaminados por este protozoário, transmitido vetorialmente por pequenos insetos do Gênero Phlebotomus spp. no velho Mundo e Lutzomyia spp. nas Américas, encontrados na região Tropical do planeta, com 1,5 Milhão de novos casos todos os anos. Este parasita desencadeia diferentes níveis da doença, em um espectro que varia desde a moléstia cutânea autolimitada (tegumentar) até a visceral (kala-azar), com acometimento de órgãos vitais, levando à morte caso não tratada (WHO, 2004).

A leishmaniose cutânea é a manifestação clínica de maior ocorrência ao redor do globo (mais de $90 \%$ dos casos), inclusive no Brasil, e pode ser dividida em três grupos, de acordo com as apresentações clínicas que ocorrem:

1-Leishmaniose cutânea: forma mais freqüente da doença, com lesões formadas, geralmente, no local da picada do inseto, sem disseminação à distância e com tendência de cura espontânea.

2-Leishmaniose cutâneo-mucosa: com lesões tanto na pele quanto na mucosa das vias aéreas superiores, com intensa atividade imunopatológica e metastatização das lesões.

3-Leishmaniose cutânea difusa: forma mais rara da doença, com inúmeras lesões nodulares disseminadas por todo o tegumento, ricas em parasitas, caracterizando uma anergia. (MAYRINK et al, 1979; CUNNINGHAM, 2002).

São conhecidas pelo menos treze espécies de Leishmania spp. causadoras de alguma variação da Leishmaniose Tegumentar Americana (LTA), agrupadas em dois grandes grupos de Subgêneros, denominados 'Complexos', conforme as características morfológicas do agente causador (LAINSON e SHAW, 1987). São eles:

- Leishmania (Leishmania), que inclui as espécies patogênicas para seres humanos L. amazonensis, L. mexicana, L. pifanoi, e L. venezuelensis.

- Leishmania (Viannia), que inclui L. brasiliensis, L. guyanensis, L. lainsoni, L. naiffi, L. panamensis, L. peruviana, L. shawi, L. lindembergi e L. colombiensis.

A doença ocorre nas florestas tropicais, tendo como reservatórios diferentes mamíferos, principalmente roedores; nas cidades, os cães errantes ou domésticos são os principais reservatórios, sendo considerados responsáveis por grande parte da transmissão da doença em áreas endêmicas do Brasil. Porém, além dos cães, outros mamíferos, são passíveis de contaminação por Leishmania spp. (SAVANI et al., 1999). 


\subsection{Morfologia e Metabolismo Celular}

Os protozoários do Gênero Leishmania spp. são dimórficos, apresentando-se sob a forma amastigota no hospedeiro vertebrado, e promastigota no inseto vetor e em culturas axênicas in vitro (PIRMEZ, 1992). Ainda sobre as formas promastigotas, já foram descritas na literatura duas populações distintas de apresentação dos parasitas: as procíclicas, fase em que há um crescimento exponencial do número de parasitas no interior do intestino, e as metacíclicas, presentes na região anterior do tubo digestório do inseto, quando os parasitas param de se reproduzir e preparam-se para infectar um novo hospedeiro (MUSKUS \& VILLA, 2002). Em estudos anteriores BONETTI e colaboradores (2002), utilizando moléculas marcadas com Trício $\left({ }^{3} \mathrm{H}\right)$, que são incorporadas no metabolismo de proteínas e na síntese de material nucléico, verificaram a provável existência dessas duas populações também em cultura, o que ficou comprovado no atual trabalho, no qual serão priorizadas as características da forma promastigota das espécies dos parasitas causadores de leishmaníase tegumentar.

Não existem diferenças significativas entre as formas promastigotas destas espécies de Leishmania spp. no que diz respeito à morfologia (FURTADO, 1987). As formas promastigotas destes parasitas apresentam membrana citoplasmática, com invaginação na sua parte posterior onde se localizam os desmossomos, organelas responsáveis pela fixação do parasita às outras células. No citoplasma, observam-se estruturas semelhantes às das células humanas, como mitocôndrias e retículo endoplasmático, além de outras organelas como cinetoplasto e corpo parabasal (de onde surge o flagelo), acantossomo, glicossomo, corpo multivesiculado e vacúolo (Vickerman, 1974), como pode ser observado na Figura 1.

O núcleo é composto por 36 cromossomos que albergam uma carga genômica de $35 \mathrm{Mbp}$, além dos nucléolos, envolvidos por uma membrana nuclear. Os estudos relacionados aos genes da Leishmania têm contribuído para um melhor entendimento da etiodoença envolvida, e na busca de tratamentos mais eficazes contra $\circ$ parasita (OULLETTE et al., 2003).

Seu metabolismo para obtenção de energia, quando na fase promastigota, é estritamente aeróbico e, quando submetida aos meios sem presença de oxigênio, demonstra uma brusca redução de suas atividades como, por exemplo, a degradação de glicose (Van Hellemond et al., 1997). Suas mitocôndrias utilizam glicólise e oxidação de prolinas para a formação das Adenosinas Trifosfatos (ATPs), sua forma de armazenar 
energia (ALVÁREZ-FORTES et al., 1998).

A superfície celular é composta por diferentes moléculas, relacionadas com a facilitação da entrada e a sobrevivência do parasita nos diferentes hospedeiros. As duas principais estruturas expressas na membrana são uma metalloproteinase de $63 \mathrm{Kda}$ (gp63, leishmanolisina) e os lipofosfoglicanos (LPG).

A gp63, considerada altamente conservada entre as diferentes espécies deste protozoário, é a principal molécula de superfície (MSP) das formas promastigotas, sendo que sua expressão e estrutura conformacional, estão diretamente relacionadas à ligação do parasita com receptores dos Macrófagos do hospedeiro vertebrado, como por exemplo, o Mac-1 (Membrane Attack Complex-1), além de conferir resistência contra a ação do Sistema Complemento, na fase inicial da infecção (BRINTTIGHAM et al., 1995). No inseto vetor a expressão da gp63 aumenta durante a metaciclogênese, demonstrando sua importância no processo de transição entre os diferentes hospedeiros (YAO et al., 2005).

Ancorados por moléculas de glicosil-fosfatidilinositol (GPI) ou secretados para o meio, os lipofosfoglicanos constituem outro importante grupo de moléculas de superfície dos parasitas. Distribuídos por toda membrana celular e no flagelo, estão relacionados com a fixação da Leishmania ao epitélio intestinal do inseto vetor, durante a fase de reprodução, e a adesão às diferentes células da resposta imune do hospedeiro vertebrado. Diferenças de quantidade e estrutura molecular também são verificadas durante o processo de metaciclogênese (MAHONEY et al., 1999).

Moléculas intracelulares presentes no citoplasma, como as heat shock proteins e cisteína-proteinases, garantem a sobrevivência durante a transição e adaptação do protozoário aos diferentes hospedeiros, processo no qual ocorre extrema modificação dos micro ambientes (GARLAPATI et al., 1999; SOARES et al., 2003). 


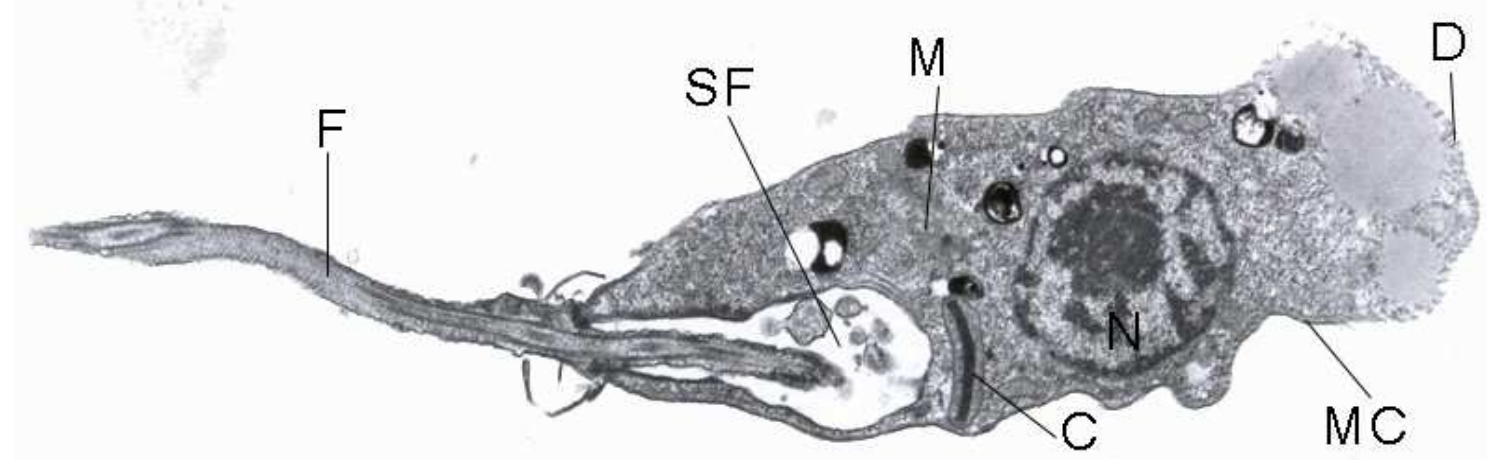

Figura1: Microscopia eletrônica de forma promastigota de Leishmania amazonensis.

F - flagelo; SF - saco flagelar; M - mitocôndria; D - desmossomos; C - cinetoplasto; N núcleo e MC - membrana citoplasmática.

\subsection{Ciclo de vida}

O ciclo de vida da Leishmania spp é heteroxeno, envolvendo um reservatório invertebrado, o inseto vetor, e um hospedeiro vertebrado (Figura 2).

No trato digestório do inseto as Leishmania spp. apresentam-se na forma promastigota, têm 10-15 $\mu \mathrm{m}$ de comprimento, vivem na luz do intestino, alimentando-se de nutrientes oriundos da digestão, e se desenvolvem passando por múltiplos estágios até atingirem uma forma denominada promastigota metacíclica, sem capacidade de divisão. Algumas alterações fisiológicas no tubo digestório, como a alteração do $\mathrm{pH}$, sinalizam para os protozoários que o inseto irá se alimentar novamente (repasto sangüíneo), fazendo com que eles migrem para a probóscida do flebotomíneo.

Ao picar o hospedeiro vertebrado, o inseto inocula um pouco de saliva, antes de sugar o sangue. Ao mesmo tempo em que injeta anticoagulantes, formas promastigotas de Leishmania spp são inoculadas no interstício do hospedeiro e prontamente procuram se instalar em células nucleadas para garantir sua sobrevivência. Normalmente as células infectadas são as do sistema primário de defesa, como Macrófagos, que fagocitam os protozoários. Quando internalizados, estes parasitas permanecem em um vacúolo parasitóforo onde se transformam em amastigota, sua forma de vida nas células do hospedeiro. As amastigotas (3-5 $\mu \mathrm{m}$ de diâmetro) se multiplicam diversas vezes por bipartição até que rompem a membrana da célula infectada, permitindo que novas células sejam infectadas pelos protozoários, com um tempo de incubação variando de 60 dias a 12 meses (BOGDAN \& HOLLINGHOF, 1999). 


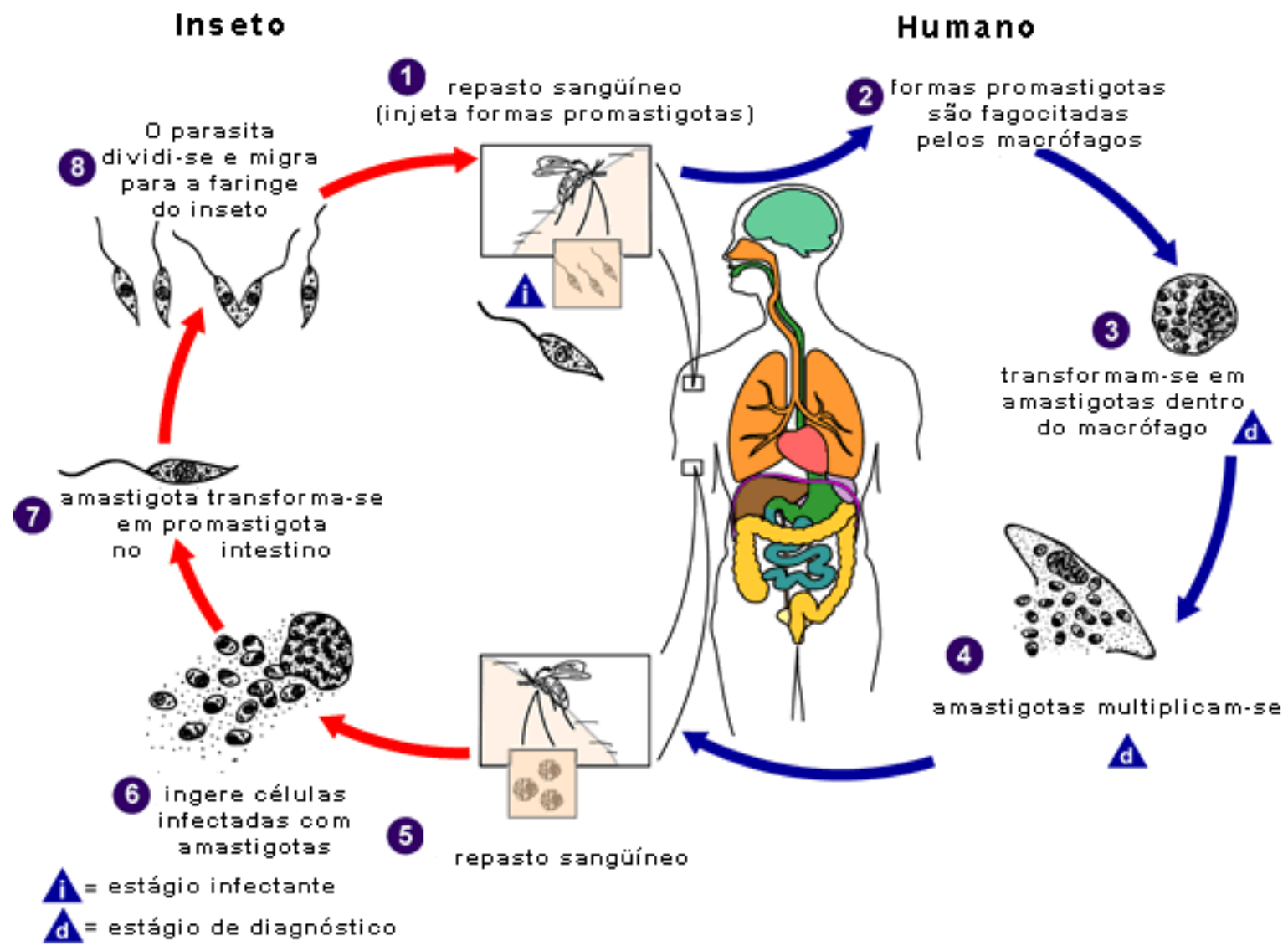

Figura2: Ciclo de vida da Leishmania spp.

Extraído e modificado de: http://www.dpd.cdc.gov/dpdx/HTML/Leishmaniasis.htm 


\subsection{Dinâmica da infecção e Resposta Imune envolvida}

Uma vez dentro do hospedeiro vertebrado, o protozoário enfrenta uma verdadeira cruzada, a fim de sobreviver aos ataques do Sistema Imunológico.O primeiro contato do parasita com o organismo ocorre logo após a picada do inseto, no espaço intersticial do tecido epitelial.

Pouco tempo depois de sua entrada, o parasita desencadeia o início da resposta imunológica inata (inespecífica), com a ativação das moléculas do Sistema Complemento e das células monocíticas fagocitárias, Macrófagos e células dendríticas da pele (Células de Langerhans) (BECKER et al., 2003). Diferente do que ocorre em outras doenças associadas à protozoários, aqui não há entrada ativa do parasita; ele apenas adere à superfície celular das células do hospedeiro permitindo a sua internalização. Quando fagocitadas pelos macrófagos, permanecem em um vacúolo (fagossomo), onde deveriam ser degeneradas por ação de moléculas específicas, como peróxido de hidrogênio $\left(\mathrm{H}_{2} \mathrm{O}_{2}\right)$ e óxido nítrico $(\mathrm{ON})$, liberadas pelos lisossomos que se fundem a este vacúolo para lisarem as Leishmanias (DAS et al., 2001). Porém, a Leishmania spp consegue retardar a formação do fagolisossomo e conseqüentemente a liberação desta enzimas hidrolíticas até concluir suas alterações morfológicas e transformar-se em amastigotas.

Já na forma amastigota, o parasita utiliza um segundo artifício de inibição da resposta imune, ele endocita e destrói parte da molécula MHC-II (Complexo Principal de Histocompatibilidade classe II), essencial no momento da apresentação do antígeno (SOUZA LEÃO et al., 1995; ANTOINE et al., 1999). Com isso, o protozoário torna mais eficiente o seu processo de multiplicar-se e disseminar-se por todo tecido sem ser destruído, ao mesmo tempo em que ativa a produção de proteínas protetoras contra a ação de enzimas líticas e citocinas (RITTIG \& BOGDAN, 2000), inibindo assim, a capacidade de destruição e reconhecimento, modulando a resposta do sistema imune específico a seu favor. A modulação do padrão de citocinas envolvidas no processo de reconhecimento e na apresentação dos antígenos do parasita para os linfócitos $T$ auxiliares ( $T$ CD4+) são essenciais para a determinação do desfecho da infecção (ANTOINE et al., 1999; PROBST et al., 2001).

Quando ocorre a produção de citocinas como o Interferon-gama (IFN-Y), Interleucina-2 (IL-2), Interleucina-12 (IL-12) entre outras, o hospedeiro desencadeia uma resposta do tipo celular (Th1) que bloqueia com eficácia a disseminação do parasita, resultando, geralmente, em cura. Por outro lado, a produção de citocinas de resposta 
humoral (Th2) como IL-4 e IL-10, possibilitam a instalação da infecção, resultando no progresso da doença (RIBEIRO DE JESUS et al., 1998).

As primeiras lesões aparecem após aproximadamente um mês de incubação. Dessa forma, a imunidade na leishmaniose é complexa e tem resultado em inúmeros estudos, bastante elucidativo, de imunologia celular humana, como a descoberta dos subgrupos de linfócitos Th1 e Th2 (BRETSCHER et al, 1997). 


\subsection{Diagnóstico}

A infecção por espécies de Leishmania spp relacionadas à doença cutânea não leva ao aparecimento de sinais e sintomas clínicos na maioria das vezes. Entretanto para a pequena parcela de indivíduos que desenvolvem as lesões é importante um diagnóstico preciso ainda no início da doença.

A avaliação clínica muitas vezes não é suficiente para o diagnóstico de leishmaniose cutânea, por este motivo o diagnóstico laboratorial se faz necessário na maioria dos casos.

A pesquisa de parasitas presentes em material de biópsia ou raspados da borda das lesões costuma render bons resultados diagnósticos. De baixo custo operacional, consiste na observação dos parasitas em microscópio óptico comum, após sua impressão em lâminas de vidro e coloração por Giemsa. Em pacientes com lesões granulomatosas, ou úlceras em estado avançado, o número de parasitas está reduzido, não sendo possível a sua visualização. Nestes casos são necessários ensaios imunológicos para a detecção de anticorpos específicos produzidos pelo paciente.

A intradermoreação (reação de Montenegro) é a técnica de preferência para estes casos. Consiste na injeção de antígeno formalizado de Leishmania na face anterior do braço do paciente e verificação da formação de pápula eritematosa após o terceiro dia. A presença de reação indica a infecção. Esta metodologia costuma ser positiva em 95\% dos pacientes infectados.

Nos laboratórios dos centros urbanos de regiões endêmicas para a leishmaniose são realizados também ensaios imunoenzimáticos in vitro (ELISA) para a detecção de anticorpos produzidos contra o parasita no soro do paciente. Esta metodologia possui alta especificidade e sensibilidade, porém, é mais custosa para os serviços Públicos, não sendo a primeira opção de escolha para a realização do diagnóstico.

Em laboratórios de pesquisa, utiliza-se a técnica de Biologia molecular conhecida como Reação em Cadeia da Polimerase (PCR), na qual o material genético do parasita proveniente de diferentes materiais biológicos, pode ser amplificado e identificado. Entretanto, discute-se a valia desta técnica no diagnóstico da doença, uma vez que o DNA do parasita pode ser detectado mesmo passado muitos anos da infecção. (COURA, 2005; REY, 2002). 


\section{6. Tratamento}

Em todo o mundo a leishmaniose cutânea é tratada com doses subcutâneas dos antimoniais pentavalentes Stibogluconato de Sódio (Pentostan) e Antimoniato de Meglumina (Glucantime) (WHO, 2004). Entretanto, por ser um tratamento longo, dolorido e com freqüente presença de efeitos colaterais, é, muitas vezes, abandonado pelo paciente, que acredita estar curado após as primeiras doses, devido ao controle do desenvolvimento das lesões (STRICKLAND, 2000).

Atualmente utilizam-se outros fármacos, associados ou não, para o tratamento de pacientes com leishmaniose, entre eles a Pentamidina e o antifúngico Anfotericina B, com resultados satisfatórios em pacientes que não respondem ao tratamento com as drogas de primeira linha (BALAÑA-FOUCE et al., 1998; MURRAY, 2001; SINGH \& SIVAKUMAR, 2004).

Outras linhas de pesquisa estão em desenvolvimento, entre elas a utilização dos antimoniais em associação com imunoterápicos (MAYRINK et al., 2006) e, mais recentemente, antimoniais irradiados (BORBOREMA, 2005).

Estão sendo testadas por diversos grupos de pesquisa, vacinas veterinárias e humanas, que mostraram resultados controversos no período e qualidade de proteção contra o parasita (CARDOSO et al., 2003; BORJA-CABRERA et al., 2004). 


\subsection{A Radiação lonizante}

A radiação ionizante possui dois tipos de ação: direta ou indireta. Na primeira, ocorre uma ação direta sobre a molécula alvo com transferência de energia, provocando ionização e alterações nas propriedades físico-químicas e na estrutura secundária e terciária dos polímeros, além de perda de função biológica. Essas mudanças estão relacionadas com a perda da atividade enzimática, hormonal ou tóxica e com as alterações das propriedades imunológicas (HRAZDIRA e SKALKA, 1970).

O efeito indireto da radiação é maior nas soluções diluídas, na presença de oxigênio e conta com um efeito protetor de outras substâncias orgânicas presentes na solução. Este fato mostra que o efeito final diferirá de acordo com as condições de irradiação (NASCIMENTO et al., 1996). Outros fatores que também influenciam o efeito da radiação são temperatura, dose, taxa de dose e $\mathrm{pH}$.

Segundo KEMPNER (1988), os raios gama e elétrons de alta energia causam ionizações ao acaso através da massa da matéria colocada no campo de radiação. Cada ionização primária resulta na transferência de 65 elétron Volt $(\sim 1500 \mathrm{kcal} / \mathrm{mol})$ da radiação para a molécula alvo. Esta energia é absorvida por diferentes mecanismos atômicos e moleculares, incluindo excitações, ionizações e formação de radicais livres. Alguns desses mecanismos resultam em mudanças irreversíveis na macromolécula por quebras de ligações covalentes e mudanças conformacionais.

Uma vez que a água constitui a grande maioria do material biológico das moléculas, muitas das interações da radiação resultam na produção de $\mathrm{OH}$, elétron aquoso, $\mathrm{H}_{2} \mathrm{O}_{2}$ e uma variedade de outros produtos potencialmente danosos. Quando em solução, esses produtos da radiólise da água, podem difundir e reagir com macromoléculas bioquimicamente ativas, causando perda de atividade biológica (NASCIMENTO et al, 1996).

No caso da radiação ionizante, a espécie mais reativa gerada pela radiólise da água é o radical hidroxila $\left(\mathrm{OH}^{\square}\right)$ (CHAPMAN, 1973) que junto com o ânion superóxido $\left(\mathrm{O}_{2}{ }^{\circ}\right)$, o elétron aquoso e o peróxido de hidrogênio $\left(\mathrm{H}_{2} \mathrm{O}_{2}\right)$ são capazes de produzir dano às moléculas (GREENSTOCK, 1981).

Diversos trabalhos utilizando radiação ionizante como ferramenta para a produção de fármacos e imunógenos contra diferentes parasitas, vêm sendo realizados há alguns anos. Em 1993, SONG e colaboradores irradiaram, com doses aproximadas de 550 Gy, cistos de $T$. gondii teciduais e demonstraram que estes cistos perderam completamente 
sua capacidade de infecção. Ainda com T. gondii, foram feitos estudos de irradiação a 255 Gy, que resultaram em esterilização das formas infectantes do protozoário (HIRAMOTO et al., 2002). Outro estudo, feito com protozoários do gênero Trypanosoma cruzi, irradiados e inoculados em camundongos, mostrou que os parasitas tiveram sua capacidade de infecção inibida de acordo com a dose de radiação recebida e a cepa utilizada (TRISCHMANN, 1982).

Em trabalhos anteriores BONETTI e colaboradores $(2000 ; 2002 ; 2005)$ utilizaram a radiação ionizante em formas promastigotas de Leishmania amazonensis, e demonstraram a permanência da viabilidade celular, mesmo com altas doses, com perda da capacidade de reprodução do parasita em culturas axênicas.

Desta forma, concluímos ser necessária a continuação dos estudos da ação da radiação lonizante nas formas promastigotas da Leishmania spp., para um melhor entendimento da sua eficácia como ferramenta na produção de um imunógeno irradiado. 
2. OBJETIVOS

\subsection{Geral:}

Determinar a dose ideal de radiação gama de ${ }^{60} \mathrm{Co}$ para obtenção de formas promastigotas metacíclicas de Leishmania amazonensis, avaliando a resposta imune induzida por estas formas, em diferentes modelos experimentais.

\subsection{Específicos:}

- Avaliar o efeito de diferentes doses de irradiação em cultura de formas promastigotas com doses de 25, 50, 100, 200 e 400 Gy de radiação gama;

- Determinar a dose ideal para obtenção da maior porcentagem de formas metacíclicas na cultura;

- $\quad$ Avaliar a viabilidade destes parasitas após a irradiação;

- Determinar os efeitos das proteínas do Sistema Complemento sobre as formas irradiadas ou não de Leishmania amazonensis;

- Avaliar a resposta Imune em camundongos de diferentes linhagens utilizando Leishmania amazonensis irradiada com diferentes doses. 


\section{METODOLOGIA}

Todos os sais e demais reagentes utilizados são de qualidade pró-análise, sendo a água, purificada em sistema Milli $Q$ (Millipore ${ }^{\circledR}$ ), com resistividade de $18.2 \mathrm{M} \Omega$. Reagentes específicos têm sua fonte citada ao longo do texto.

3.1. Cultivo de células RAW (RASCHKE et al., 1978): Células RAW 264.7 (macrophagelike cell line) foram cultivadas em meio RPMI 1640 (SIGMA ${ }^{\circledR}$ ) com 10\% de soro fetal bovino inativo $\left(\mathrm{CULTILAB}^{\circledR}\right)$, em estufa à $37^{\circ} \mathrm{C}$, e atmosfera de $5 \%$ de $\mathrm{CO}_{2}$. Para os ensaios de infecção in vitro, a concentração de células utilizada foi de $2 \times 10^{5} / \mathrm{ml}$.

3.2. Cultivo dos Parasitas (LEMESRE et al., 1988): Formas promastigotas da cepa MPRO/BR/72/LV79 de L. (L.) amazonensis, gentilmente cedidas pela Dra. Silvia Celina Alfieri, do Departamento de Parasitologia do Instituto de Ciências Biomédicas da USP, isoladas de pata de camundongos previamente infectados, foram cultivadas em meio RPMI $1640\left(\right.$ SIGMA $\left.^{\circledR}\right)$, pH 7,4, acrescido de $20 \%$ de soro fetal bovino $\left(\right.$ CULTILAB $^{\circledR}$ ), e $0.25 \%$ de Hemina liofilizada, diluída em solução de $\mathrm{NaOH} 1 \mathrm{M}$. A cultura foi mantida em estufa B.O.D. à $24 \stackrel{\circ}{\circ}$.

3.3. Irradiação: Para o processo de irradiação, as Leishmanias foram contadas em câmara hematocitométrica (Neubauer) e transferidas para o meio HBSS (Hank's Balanced Salt Solution, pH 7,4 $\pm 0,2$ ), que mimetiza os nutrientes encontrados na luz do intestino do inseto, a fim de evitar transformações na forma de apresentação do parasita que pudesse mascarar os resultados do processo. A irradiação foi realizada no Centro de Tecnologia da Radiação (CTR) do Instituto de Pesquisas Energéticas e Nucleares IPEN/CNEN-SP, em fonte de ${ }^{60} \mathrm{Co}$ (GAMMACELL, Atomic Energy of Canadá Ltd.), de forma homogênea, em presença de oxigênio, a uma taxa de dose de 3,29 KGy/hora. As doses de radiação utilizadas foram de 25, 50, 100, 200 e 400 Gy. Para os ensaios de imunização as doses utilizadas foram $100 \mathrm{~Gy}$ e $400 \mathrm{~Gy}$, com atenuação de $90 \%$. Após serem submetidas à incubação com soro de cobaio, para interação com Sistema Complemento (metodologia a seguir), as amostras foram novamente irradiadas com dose de 2 KGy, provocando, assim, a morte dos parasitas. 
3.4. Ensaio de fixação de complemento (ZAKAl et al., 1998): Os parasitas irradiados com as doses de 25, 50, 100200 e 400 Gy, além dos parasitas do grupo controle que não receberam radiação, foram mantidos em meio HBSS, na concentração de $10^{7}$ parasitas/ $\mathrm{ml}$, e posteriormente colocados em uma placa de 24 poços de fundo chato, no volume de $500 \mu \mathrm{L}$ por poço. Foi então adicionado soro de cobaio nas proporções de 10 ou $20 \%$ por poço, sendo incubados por a $37^{\circ} \mathrm{C}$ por um período de três horas. Após a incubação, foi adicionada solução salina à 4 $\mathrm{C}$ para bloquear a reação. Os parasitas foram transferidos para tubos do tipo Eppendorf ${ }^{\circledR}$ e centrifugados por 10 minutos a $1800 \mathrm{rpm}$. Desprezou-se o sobrenadante, e ressuspendeu-se o pellet em $1 \mathrm{~mL}$ de HBSS. Os parasitas foram contados em microscópio óptico com auxílio de uma câmara de Neubauer.

\subsection{Ensaios para determinação do tempo médio de metaciclogênese de Leishmania} amazonensis in vitro (PINTO-DA-SILVA et al., 2002): Formas promastigotas do protozoário foram tiradas da criogênese e restabelecidas em cultura em meio RPMI, conforme descrito anteriormente. Diariamente o número de parasitas foi contado em câmara hemocitométrica (Neubauer) para determinação do tempo de metaciclogênese do parasita.

3.6. Ensaios de infecção de células RAW in vitro (SOARES et al., 1997): Para a realização deste ensaio foram utilizados parasitas irradiados com diferentes doses de radiação gama, mantidos em meio HBSS, da mesma maneira descrita no ensaio de irradiação. Foram colocadas lamínulas de $18 \mathrm{~mm}$ de diâmetro (uma por poço) em uma placa de 24 poços, recobertas a seguir com $2 \times 10^{5}$ células RAW em $500 \mu \mathrm{L}$ de RPMl e mantidas por 24 horas em estufa a $37 \stackrel{\circ}{\circ} \mathrm{C}$ com $5 \%$ de $\mathrm{CO}_{2}$. Após este período, o meio contido nos poços foi aspirado, e $2 \times 10^{6}$ parasitas $/ \mathrm{mL}$ foram acrescidas por poço. A placa permaneceu em estufa $37^{\circ} \mathrm{C}, \mathrm{CO}_{2} 5 \%$ por três horas e a seguir lavou-se a placa com salina à $4^{\circ} \mathrm{C}$. Retirou-se o sobrenadante com bomba de vácuo e foi adicionado 300 $\mu \mathrm{L}$ de metanol, por poço, por 2 minutos. Novamente retirou-se o sobrenadante com bomba de vácuo e acrescentou-se $500 \mu \mathrm{L}$ de GIEMSA $^{\circledR}$ por dez minutos. A placa foi então lavada duas vezes com água milli-Q para retirada do GIEMSA $^{\circledR}$. As lamínulas foram levantadas e mantidas inclinadas, apoiadas em pérolas de vidro para secagem, por um período de 18 horas em estufa $37^{\circ} \mathrm{C}$, evitando assim que ficassem presas ao fundo da placa. Retirou-se as lamínulas dos poços e, utilizando cola de imersão (Permount ${ }^{\circledR}$ ), colou-se duas lamínulas por lâmina. Contou-se então o número de células infectadas e o 
número de Leishmania por célula infectada, para determinação da capacidade de infecção dos parasitas irradiados com as diferentes doses.

3.7. Microscopia eletrônica (DUARTE et al., 1992): A Microscopia Eletrônica foi realizada em microscópio eletrônico (JEOL), instalado na Faculdade de Medicina da USP. Amostras de formas promastigota de Leishmania amazonensis não irradiadas ou irradiadas com doses de 100 e 400 Gy, foram centrifugadas separadamente por 10 minutos a $2800 \mathrm{rpm}$, o sobrenadante retirado, e o pellet resultante foi fixado em uma solução com $3 \%$ de glutaraldeído com formaldeído em tampão cacodilato $(0,1 \mathrm{M}, \mathrm{pH} 7,0)$ por trinta minutos. Posteriormente, o material foi lavado três vezes com tampão cacodilato com $2 \%$ de sacarose e foi feita a fixação em Tetróxido de Ósmio $2 \%$ por trinta minutos. Após três novas lavagens, o material foi mantido em 5\% de acetato de uranil com 100\% de etanol (solução final: $2,5 \%$ de uranil, $50 \%$ de etanol) por cinco minutos, seguido de três lavagens em etanol $70 \%$. Os espécimes foram desidratados em 2,2 dimetoxipropano acidificado com $0,05 \mathrm{~mL}$ de $\mathrm{HCl}(1 \mathrm{M})$ por cinco minutos, sendo então colocados em solução de sulfato cúprico anidro por dois minutos. As amostras foram embebidas em acetona Epon Polybed ${ }^{\odot}$ com Araldite $502^{\circledR}(1: 1)$ por trinta minutos e novamente mergulhados mais duas vezes nesta solução por dez minutos. A polimerização foi dada a $100^{\circ} \mathrm{C}$ por uma hora. Cortes semi-finos e ultrafinos foram feitos e fixados em acetato de uranil $70 \%$ em metanol.

3.8. Ensaio de imunização (BRETSCHER et al., 1997): Quatro diferentes linhagens de camundongos foram imunizadas: Balb/c, C57/bl, Balb/c ${ }^{n u / n u}$, e Balb/c scid , sendo os dois últimos, manipulados em ambiente estéril. As imunizações foram realizadas em intervalos quinzenais com doses de $100 \mu \mathrm{l}$, contendo $10^{6}$ parasitas em meio de cultura HBSS, previamente irradiados conforme protocolo já descrito, com inóculos subcutâneos na base da cauda. Após quinze dias do último inoculo, os camundongos foram desafiados com a mesma concentração de parasitas não irradiados e viáveis, na pata posterior traseira. Antes de cada um dos quatro inóculos, e nos 45 dias posteriores, sempre em intervalos quinzenais, foi colhido sangue da ponta da cauda de cada animal, em papel-filtro, para posterior preparo das eluições, utilizados nas análises sorológicas. Os papéis-filtro utilizados para a coleta do sangue dos camundongos foram cortados em discos de contendo em torno de $5 \mu \mathrm{L}$ de sangue e colocados em microtubos do tipo Eppendorf ${ }^{\circledR}$, em $500 \mu \mathrm{L} /$ disco de Tampão Fosfato, $\mathrm{pH}$ 8,5, adicionado de 0,05\% de Tween 20 e 3\% de 
leite desnatado em pó, para eluição do sangue. Os tubos foram mantidos 'overnight' sob refrigeração de $4^{\circ} \mathrm{C}$, centrifugado, e 0 sobrenadante contendo 0 soro do sangue dos camundongos, foi utilizado nos testes de ELISA. No dia do desafio e quinzenas posteriores, foi também avaliado o tamanho de ambas as patas traseiras destes camundongos, utilizando-se um paquímetro analógico de precisão (MITUTOYO ${ }^{\circledR}$ ).

\subsection{Ensaios Imunoenzimáticos (Enzyme Linked Immunossorbent Assay - ELISA):}

Este ensaio foi realizado em placa de 96 poços, fundo chato, previamente sensibilizada com Antígeno solúvel de Leishmania amazonensis. Após a sensibilização 'overnight', a placa foi lavada com PBSTL (Tampão Fosfato, pH 8,5, acrescido de 0,03\% de Leite desnatado e $0,02 \%$ de $\operatorname{Tween}^{\circledR}$ ). Aplicou-se, então $100 \mu \mathrm{L}$ por poço, de amostra eluída do papel-filtro, e incubou-se a $37^{\circ} \mathrm{C}$ por uma hora. Realizou-se um novo ciclo de lavagens com PBSTL por três vezes. Foi aplicado conjugado anti-lgG de camundongo $\left(\right.$ SIGMA $\left.^{\circledR}\right)$ na diluição de 1:20.000 em PBSTL sob agitação. A placa foi levada à estufa a 37ㅇ $\mathrm{C}$ por mais uma hora. Lavou-se com PBSTL por seis vezes e foram aplicados $100 \mu \mathrm{l}$ de OPD (ortofenilenodiamina $1 \mathrm{mg} / \mathrm{ml}, \mathrm{H}_{2} \mathrm{O}_{2}$ 0,03\% em Tampão fosfato - citrato $0,2 \mathrm{M} \mathrm{pH} 5,0$ ) por trinta minutos em câmara escura. Cinqüenta microlitros de $\mathrm{HCl} 4 \mathrm{~N}$ foram adicionados para interromper a reação e, em seguida, foi feita a leitura em leitor de microplacas (MultiscanUNISCIENCE ${ }^{\circledR}$ ) em comprimento de onda de $492 \mathrm{~nm}$. Os resultados foram analisados em gráficos elaborados no Graph-Pad Prism 3.0.

3.10. Sub-classes de Imunoglobulinas (VENKATESAN \& WALKELIN, 1993): Este ensaio segue protocolo semelhante ao descrito acima, com diferenciação apenas no conjugado de anticorpos utilizados. Foram utilizadas três placas de 96 poços, previamente sensibilizadas com antígenos de Leishmania amazonensis. Aplicou-se os diferentes conjugados, um em cada placa: anti-lgG1, anti-lgG2a e anti-lgG2b de camundongo, conjugado a peroxidase (Southern Biotechnology Associates ${ }^{\circledR}$ ) na diluição de 1:2.000 em PBS. As placas foram incubadas a $37^{\circ} \mathrm{C}$ por mais uma hora. Lavou-se com PBSTL por seis vezes e foram aplicados $100 \mu \mathrm{l}$ de OPD (orto-fenilenodiamina $1 \mathrm{mg} / \mathrm{ml}, \mathrm{H}_{2} \mathrm{O}_{2}$ 0,03\%

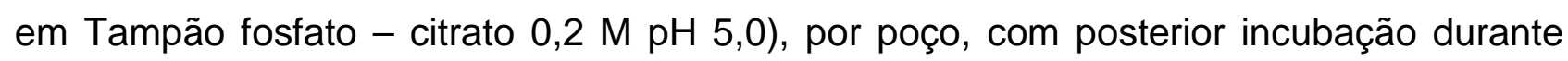
trinta minutos em câmara escura. Cinqüenta microlitros de ácido cítrico 0,2M foram adicionados, por poço, para interromper a reação e, em seguida, foi feita a leitura em leitor de microplacas (Multiscan-UNISCIENCE ${ }^{\circledR}$ ) em comprimento de onda de $450 \mathrm{~nm}$. Os resultados foram analisados em gráficos elaborados no Graph-Pad Prism 3.0. 
3.11. Reação em cadeia da Polimerase (ULIANA et al., 1994): O material a ser processado por reação em cadeia da polimerase (PCR), para amplificação e detecção de DNA de Leishmania amazonensis, foi coletado da pata imunizada e/ou infectada dos camundongos manipulados nos ensaios de imunização, utilizando uma lâmina de bisturi, pinças e tesoura estéreis.

3.11.1 Extração das amostras: As frações de tecido retiradas foram colocadas em tubos cônicos do tipo Eppendorf ${ }^{\circledR}$, lavada por duas vezes com tampão Tris-EDTA (Tris-base 10 mM, EDTA 01 mM, pH 8,0) e centrifugadas a 10.000 rpm, por 5 minutos. Adicionou-se 1 $\mathrm{mL}$ de Proteinase $\mathrm{K}(20 \mathrm{mg} / \mathrm{mL})$ e $10 \mu \mathrm{L}$ de SDS 20\%. Após 1 hora de incubação à $42{ }^{\circ} \mathrm{C}$, sob agitação, foi realizada nova centrifugação à 10.000 rpm por 5 minutos. Recolheu-se o sobrenadante, que foi transferido para outro tubo semelhante. Três lavagens foram realizadas utilizando-se fenol/clorofórmio (v/v) por centrifugação à 12.000 rpm por cinco minutos cada. O sobrenadante foi precipitado com 0,1 Volume de Acetato de Sódio 3M (pH 5,8) e 2 Volumes de Etanol Absoluto gelado. Após esta etapa o material foi incubado por 18 horas à $-20^{\circ} \mathrm{C}$. Passado este período centrifugou-se os tubos à 10.000 rpm, por 5 minutos, e o sobrenadante foi descartado. Novamente foram realizadas três lavagens com Etanol $70 \%$ por 3 minutos à 10.000 rpm. Após a secagem dos tubos à temperatura ambiente, o pellet foi ressuspenso em $50 \mu \mathrm{L}$ de água bidestilada.

3.11.2. Preparação da mix: $2,0 \mu \mathrm{Lde}$ DNTPs ( $10 \mathrm{mM}), 2,5 \mu \mathrm{L}$ de Tampão $(50 \mathrm{mM}$ de $\mathrm{KCl}$ + $10 \mathrm{mM}$ de Tris, $\mathrm{pH} 8,3), 2 \mu \mathrm{L}$ de $\mathrm{MgCl} 2$ (50 mM), 0,1 pmol de primers, 0,4 $\mu \mathrm{L}$ de Taq Polimerase (Life Technologies) e 12,5 $\mu \mathrm{L}$ de água bidestilada. Vinte microlitros desta preparação foi adicionada a cada tubo, juntamente com os materiais de biópsia a serem analisados Centrifugou-se o preparado a 10.000 rpm por 1 minuto para homogeneização e retirada de bolhas.

3.11.3. Desenho dos primers: Para a realização da amplificação do material genético de Leishmania amazonensis por PCR foram utilizados dois primers complementares para subunidades de DNA ribossomal (SSU rDNA) que contém regiões conservadas do genoma dos protozoários do Gênero Leishmania, permitindo uma caracterização precisa de sua presença no material analisado. Foram escolhidos os primers S4 (5'GATCCAGCTGCAGGTTCACC-3') e S12 (5'-GGTTGATTCCGTCAACGGAC-3’).

3.11.4. Amplificação do material: $94^{\circ} \mathrm{C}$ por 2 minutos (desnaturação inicial), a seguir 
foram realizados 35 ciclos de $94 \stackrel{\circ}{\circ}$ por 1 minuto (desnaturação), $55 \stackrel{\circ}{\mathrm{C}}$ por 1 minuto (anelamento), $72{ }^{\circ} \mathrm{C}$ por 2 minutos para a extensão final.

3.11.5. Eletroforese: O produto de amplificação do PCR foi analisado em gel de agarose $1 \%$ ( $1 \%$ de agarose em tampão Tris-EDTA), sendo o tamanho da banda esperada em torno de 520 pares de base (bps). Preparado o gel, as amostras foram colocadas nos respectivos poços sob uma corrente de $90 \mathrm{~V}$. O padrão do peso molecular utilizado apresenta bandas variando em 100 pares de base. A revelação foi obtida com a adição de Brometo de Etídio e observado no negatoscópio.

3.12. Análise estatística: Os resultados gerados com os ensaios de imunizações foram submetidos à análise de variância (ANOVA), com teste posterior de Bonferroni, afim de avaliar diferenças significativas entre os grupos de camundongos imunizados, frente a animais controle, utilizando a probabilidade de igualdade menor que $0.05(\mathrm{p}<0.05)$. 


\section{RESULTADOS}

\subsection{Ensaios para determinação do tempo médio de metaciclogênese de Leishmania} amazonensis in vitro

Os primeiros resultados correspondem ao ensaio de metaciclogênese das formas promastigotas, não irradiadas, em meio RPMI 1640. O ensaio foi reproduzido duas vezes e os resultados mostrados na Figura 3 expressam a média obtida em ambos:

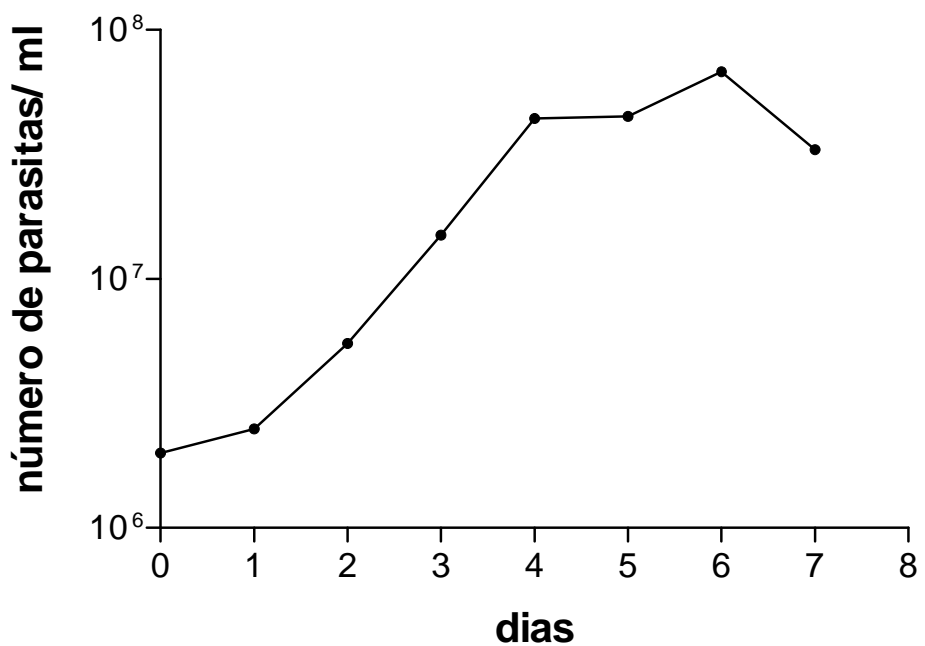

Figura 3: Concentração do número de formas promastigotas de Leishmania amazonensis por ml, cultivadas em meio RPMI durante 7 dias.

A concentração do número de promastigotas que inicialmente era de $2 \times 10^{6} / \mathrm{ml}$, cresceu rapidamente nos quatro primeiros dias atingindo $4,4 \times 10^{7}$ parasitas $/ \mathrm{ml}$ no dia 4 . Após esta fase houve uma estabilização do crescimento que aumentou discretamente por mais dois dias, quando então a concentração de parasitas começou a diminuir consideravelmente. 
O segundo ensaio a ser realizado foi a determinação da concentração das formas promastigotas por $\mathrm{mL}$, mantidas em meio de cultura HBSS, após serem irradiadas com diferentes doses de radiação gama. A Figura 4 expressa a média obtida em duas reproduções do experimento:

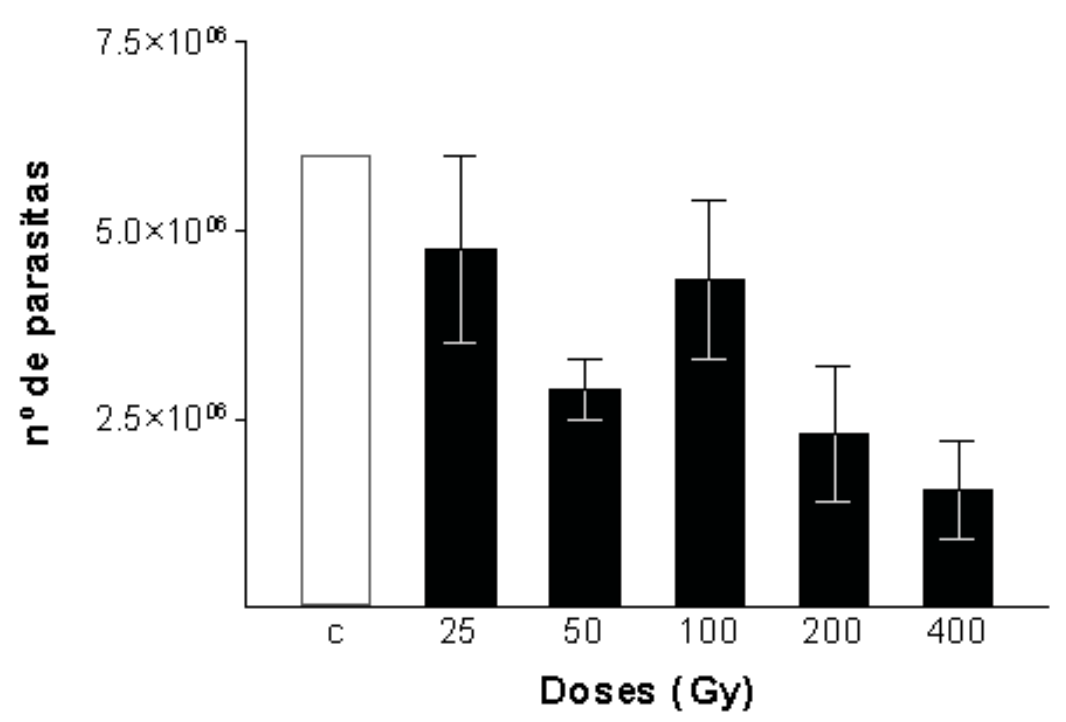

Figura 4. Concentração de Leishmania amazonensis, mantida em meio HBSS, submetidas a irradiação com diferentes doses de raios gama: 25, 50, 100, 200 e 400 Gy. A barra vazada mostra a concentração dos parasitas antes da irradiação e as barras cheias representam a concentração destes mesmos parasitas após serem irradiados.

Após a irradiação as formas promastigotas de Leishmania amazonensis sofreram redução no número de parasitas por $\mathrm{ml}$, em relação à concentração de $6 \times 10^{6}$ parasitas $/ \mathrm{ml}$, apresentada antes do processo. As doses de 25, 50 e 200 Gy reduziram gradativamente o número de parasitas. Comparativamente, a dose de 100 Gy não seguiu o padrão dose/resposta, induzindo menos danos aos parasitas. Por outro lado, a dose de 400 Gy diminuiu a concentração de parasitas para quase um terço do total inicial.

\subsection{Ensaios de infecção de células RAW in vitro:}

Os ensaios de infecção in vitro foram realizados com parasitas irradiados com diferentes doses a fim de se avaliar sua capacidade em infectar células RAW. O ensaio foi reproduzido duas vezes, e os resultados expressos na Figura 5 representam a média obtida nos experimentos: 


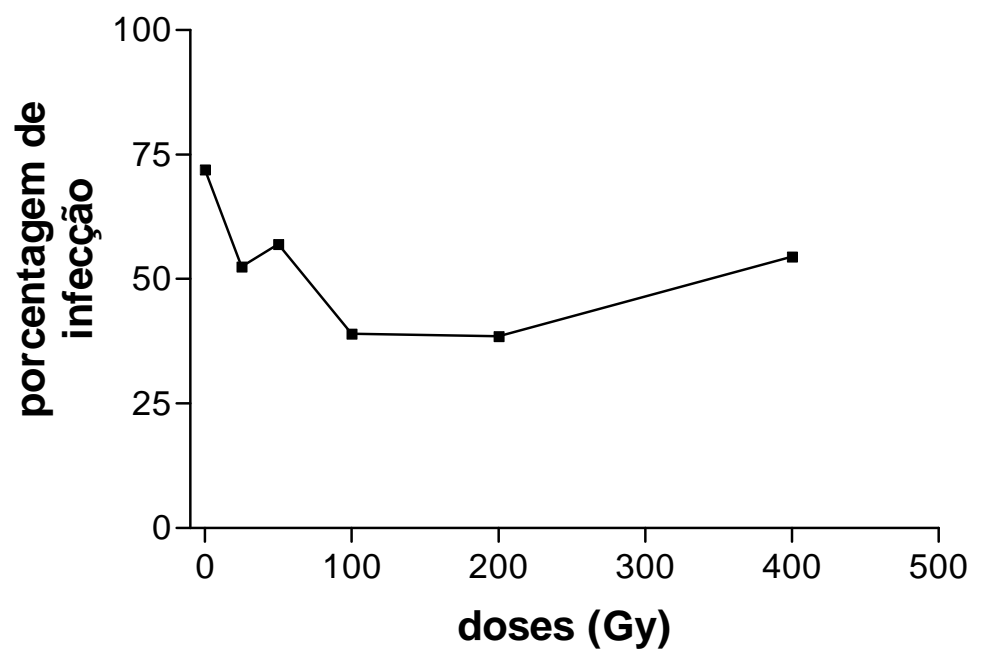

Figura 5: Porcentagem de células RAW infectadas com formas promastigotas de Leishmania amazonensis irradiadas com diferentes doses de: 25, 50, 100, 200 e 400 Gy de radiação gama $\left({ }^{60} \mathrm{Co}\right)$.

Os parasitas irradiados com as doses de 25, 100 e 200 Gy tiveram uma perda da capacidade de infecção progressivo, conforme à dose recebida. Leishmanias irradiadas com 50 e 400 Gy infectaram mais células do que aquelas irradiadas com as outras doses. 


\subsection{Ensaio de fixação de complemento:}

Para confirmar a presença predominante de formas metacíclicas de Leishmania amazonensis nas culturas irradiadas com doses variando de 25 a $400 \mathrm{~Gy}$, foram realizados ensaios de lise por proteínas do Sistema Complemento, utilizando $10 \%$ ou $20 \%$ de soro de cobaio, conforme demonstrado na Figura 6:

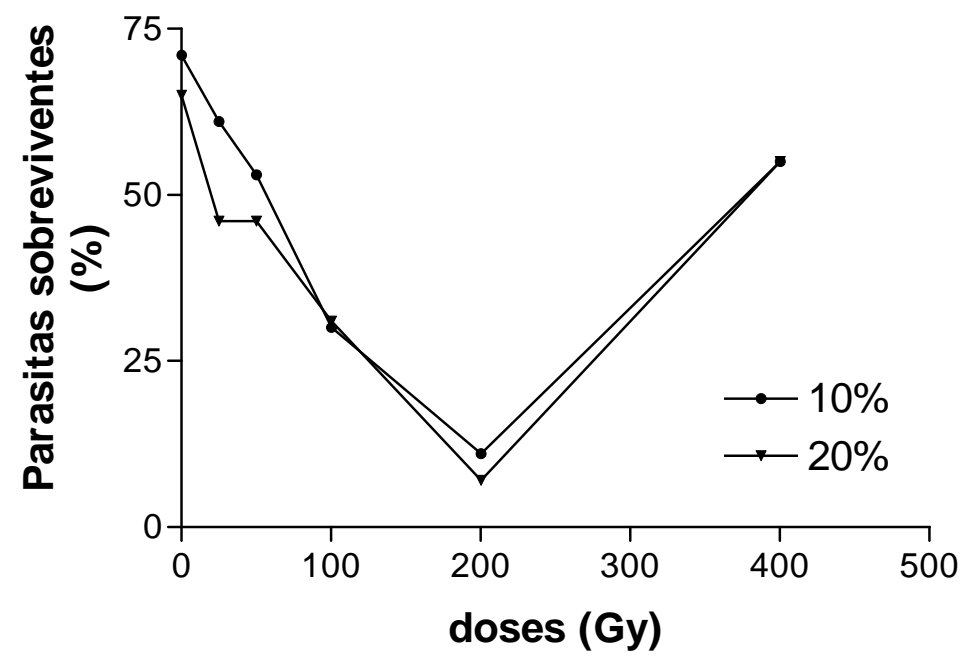

Figura 6: Porcentagem de sobrevivência das formas promastigotas de Leishmania amazonensis, em meio de cultura HBSS, irradiadas com doses de 25, 50, 100, 200 e 400 Gy de radiação gama, incubadas com diferentes concentrações de soro de cobaio.

O que se observou neste ensaio foi a diminuição progressiva da concentração de formas promastigotas de Leishmania amazonensis, de maneira proporcional ao aumento da dose de radiação gama aplicada, até a dose de 200 Gy. Já na cultura irradiada com 400 Gy, pode-se notar uma concentração de quase $75 \%$ em relação à concentração inicial de parasitas daquela cultura. No que diz respeito às diferentes concentrações de soro testadas, pode-se afirmar que ambas surtiram praticamente o mesmo efeito sob os parasitas. 


\subsection{Microscopia Eletrônica:}

Com a análise por microscopia eletrônica destes parasitas, observamos uma alteração dos padrões celulares nos parasitas irradiados, tanto com 100 Gy, quanto com 400 Gy, ocorrendo o mesmo com os parasitas submetidos à incubação frente ao Sistema Complemento, irradiados ou não, conforme demonstrado na Figura 7:

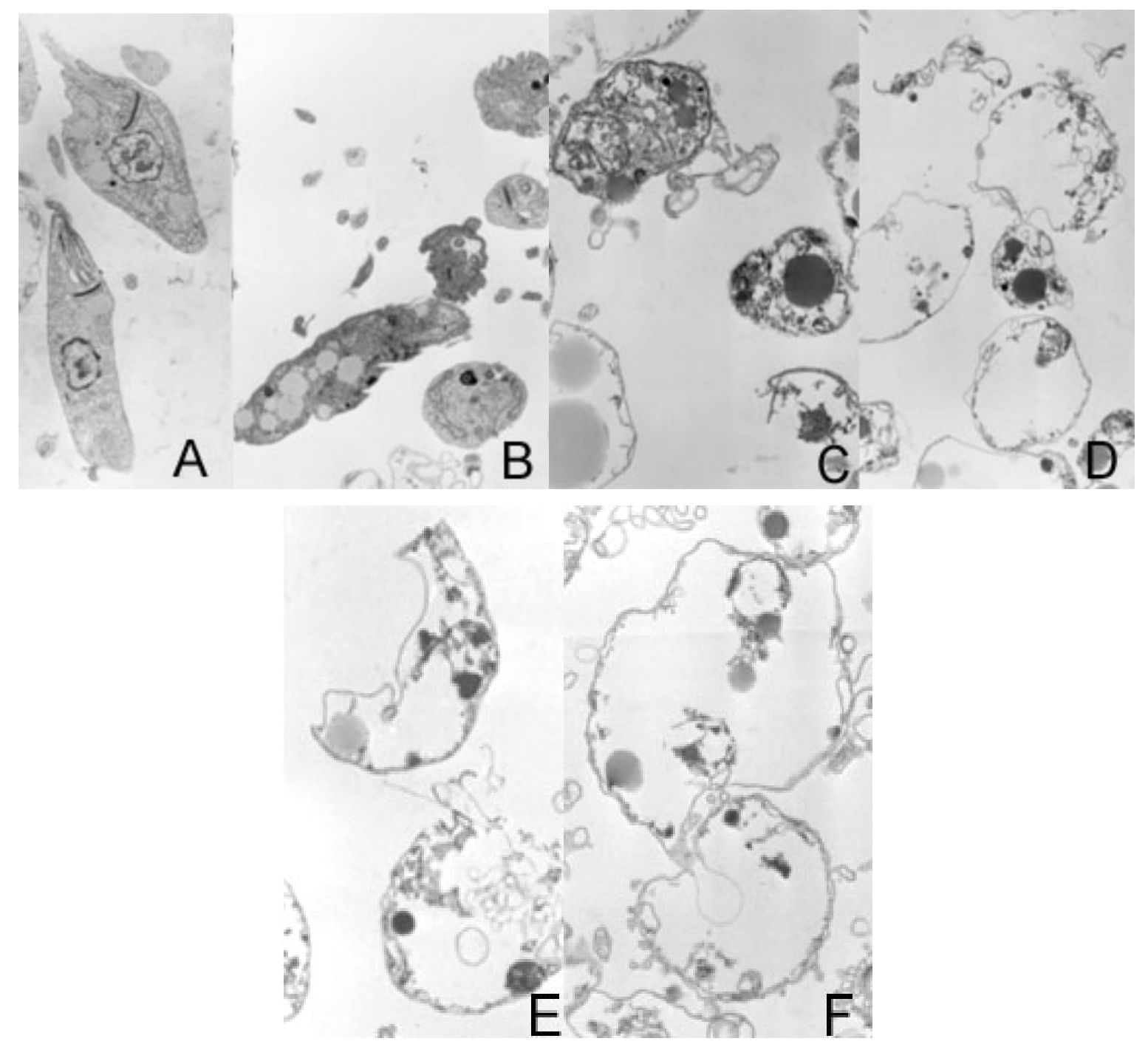

Figura 7: Fotos de Microscopia Eletrônica de formas promastigotas de Leishmania amazonensis, irradiados ou não, e submetidos, ou não, à incubação com soro de cobaio não inativado, para interação com moléculas do Sistema Complemento. (A) parasitas não irradiados, (B) parasitas não irradiados, afetados pelo Complemento, (C) parasitas irradiados com 100 Gy, (D) parasitas irradiados com 100 Gy e afetados pelo Complemento, (E) parasitas irradiados com 400 Gy e (F) parasitas irradiados com 400 Gy, sob ação do Complemento.

Observou-se nas fotos $\mathrm{A}$ e $\mathrm{B}$, que parasitas não irradiados incubados com soro de cobaios e, portanto, com moléculas do Sistema Complemento, sofrem lise celular e perda do flagelo, quando não estão em sua forma metacíclica. Já os parasitas irradiados com 
dose de 100 Gy de radiação, perderam sua forma e seu flagelo durante o processo de irradiação, sem, entretanto ter lise celular. Quando incubados com as moléculas do Complemento, há perda de material citoplasmático para o meio, inviabilizando estas células.

Com os parasitas irradiados com 400 Gy, de radiação ionizante, em meio aquoso e na presença de oxigênio, observou-se que as moléculas do Complemento, não oferecem destruição maior que o próprio processo de irradiação, com manutenção da membrana celular, apesar do aparente desarranjo citoplasmático.

Concluídos os ensaios de avaliação fisiológica e morfológica dos parasitas submetidos às diferentes doses de radiação gama $\left({ }^{60} \mathrm{Co}\right)$, deu-se início aos ensaios de imunização em modelos experimentais, utilizando camundongos de diferentes linhagens e padrões de resposta imunológica, para verificação de resistência, susceptibilidade e modulação de respostas específicas. 


\subsection{Ensaios de Imunização de modelos experimentais:}

4.5.1. Titulação de anticorpos: Parasitas irradiados com doses de 100 e 400 Gy de radiação ionizante, para seleção das formas infectantes, e novamente irradiados com 2 KGy, foram inoculados na concentração de $10^{6}$ parasitas/100 $\mu \mathrm{L}$, quinzenalmente, em camundongos de diferentes linhagens. Ao final de 45 dias os camundongos foram desafiados com parasitas não irradiados, viáveis, na concentração de $10^{4}$ parasitas em $100 \mu \mathrm{L}$. , conforme demonstrado nas figuras $8,9,10$ e 11 :

\section{Balb/c}

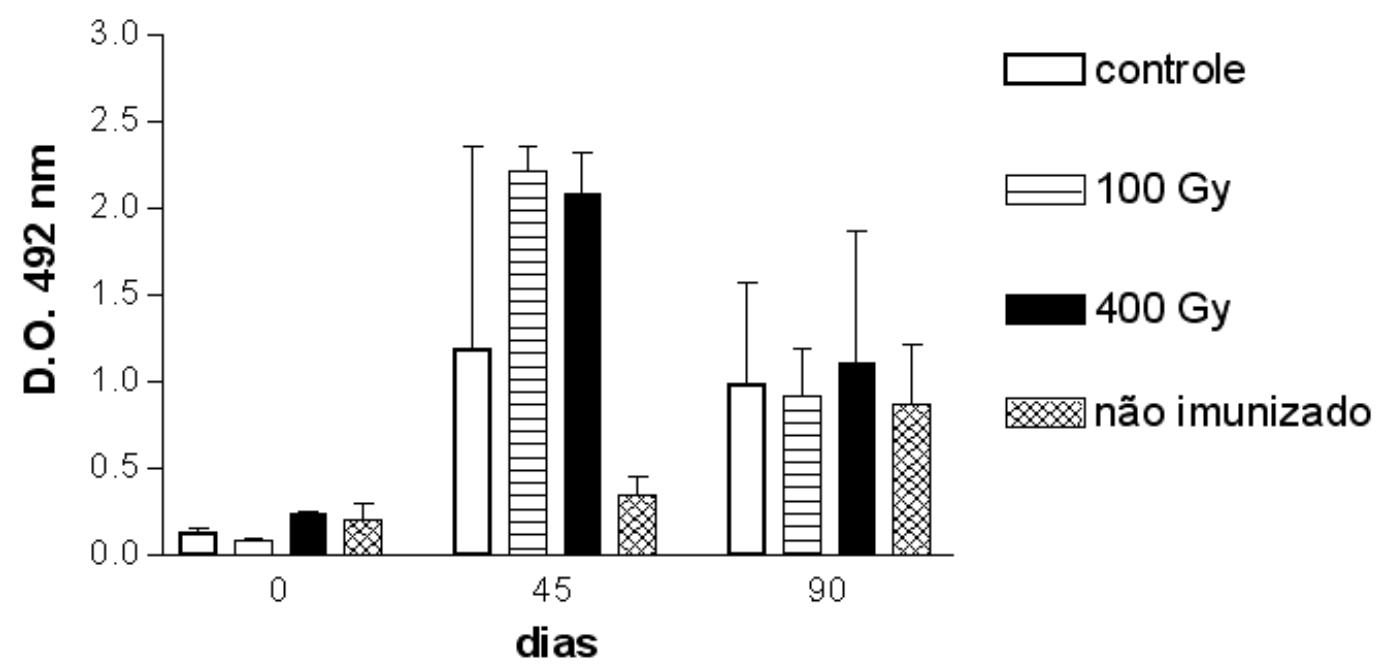

Figura 8: Densidade óptica dos títulos de anticorpos produzidos por camundongos Balb/c, no dia zero (primeira dose de imunização), dia 45 (desafio) e dia 90 (45 dias após a infecção) submetidos à três inóculos quinzenais de imunização, com $10^{6}$ parasitas/ $100 \mu \mathrm{L}$, irradiadas ou não, com posterior desafio utilizando formas promastigotas de Leishmania amazonensis viáveis.

Camundongos Balb/c imunizados com formas promastigotas de $L$. amazonensis selecionadas com diferentes doses de radiação gama responderam com altos títulos de anticorpos. Após 15 dias do inóculo da última dose imunização (dia 45) os camundongos apresentaram elevada produção de imunoglobulinas, em especial aqueles que receberam imunização com os parasitas previamente selecionados pelas doses de 100 e 400 Gy. Estes títulos de anticorpos mantiveram-se presentes ao longo dos outros 45 dias que se seguiram, ainda que seus valores tenham diminuído, igualando-se aos demais grupos, que por sua vez produziram mais anticorpos com o passar dos dias. 
c57/ bl6

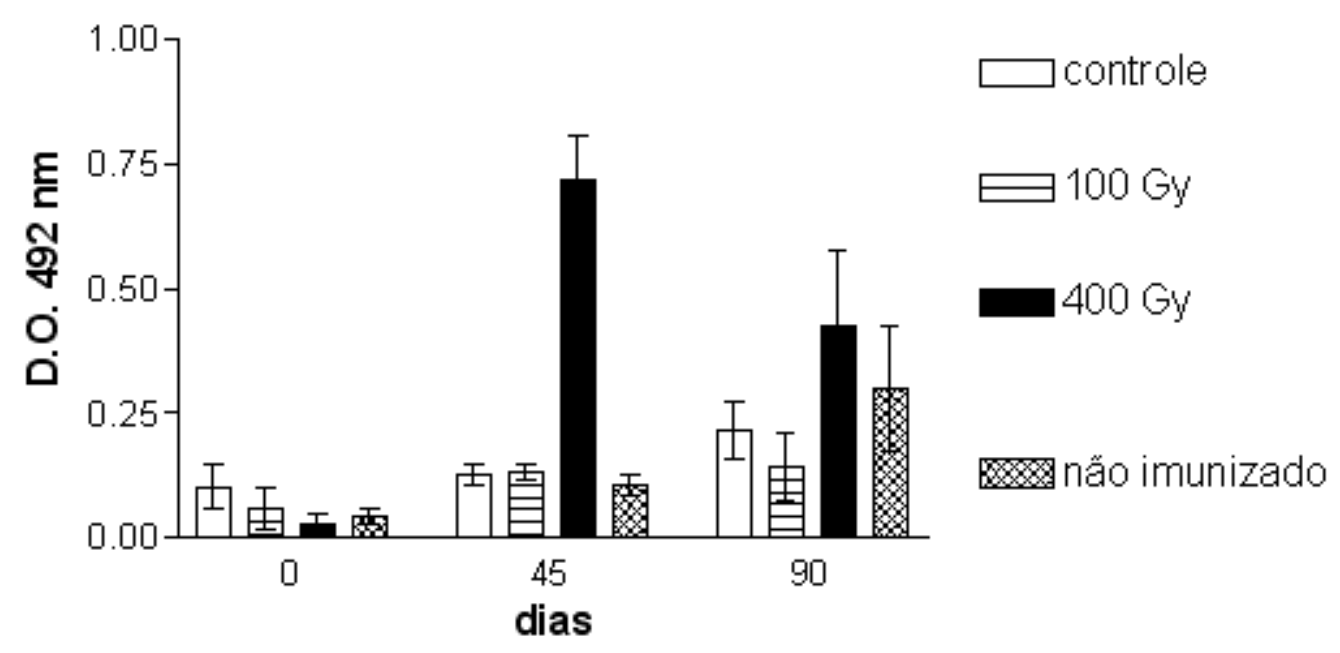

Figura 9: Densidade óptica dos títulos de anticorpos produzidos por camundongos c57/bl, no dia zero (primeira dose de imunização), dia 45 (desafio) e dia 90 (45 dias após a infecção) submetidos à três inóculos quinzenais de imunização, com $10^{6}$ parasitas/ $100 \mu \mathrm{L}$, com posterior desafio utilizando formas promastigotas de Leishmania amazonensis viáveis.

Camundongos c57/bl tiveram seus títulos de anticorpos aumentados, ainda que em menor proporção que o grupo anterior, após uma quinzena da última dose de imunização com parasitas irradiados com diferentes doses. Estes títulos aumentaram consideravelmente ao final de noventa dias, com exceção feita ao grupo imunizado com parasitas irradiados com a dose de 400 Gy de radiação gama, que apresentou uma diminuição em torno de $40 \%$ dos níveis séricos de anticorpos ao final do período. 


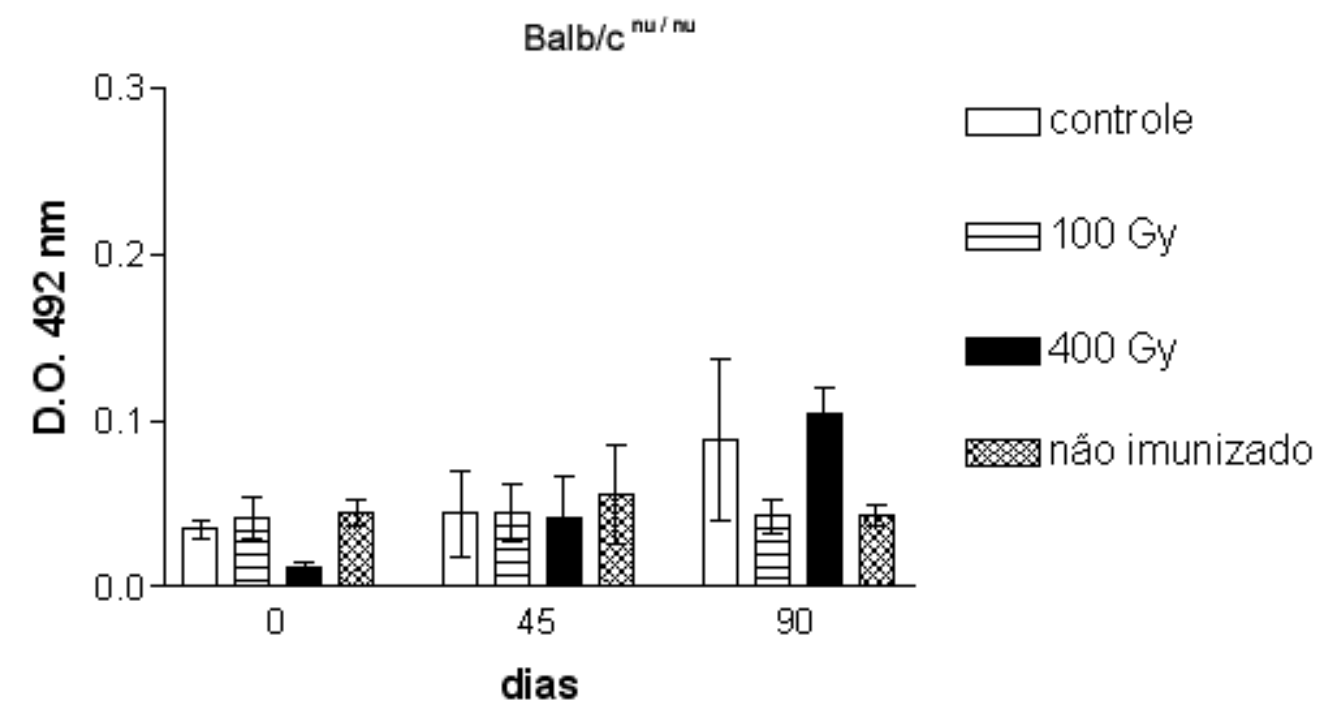

Figura 10: Densidade óptica dos títulos de anticorpos produzidos por camundongos Balb/c ${ }^{\text {nu/nu }}$ no dia zero (primeira dose de imunização), dia 45 (desafio) e dia 90 (45 dias após a infecção), submetidos a três inóculos quinzenais de imunização, com $10^{6}$ parasitas/ $100 \mu \mathrm{L}$, com posterior desafio utilizando formas promastigotas de Leishmania amazonensis viáveis.

Camundongos nude, desprovidos de parte de seu repertório celular, praticamente não responderam à imunização com parasitas irradiados, nem à infecção com parasitas nativos, durante todo o período. Os títulos de anticorpos produzidos por todos os grupos não atingiu um limiar mínimo que pudesse ser considerado uma resposta específica, mediada pela produção de anticorpos. Esta linhagem de animais, não possui células $T$, responsáveis pela condução e uma resposta específica eficiente. 


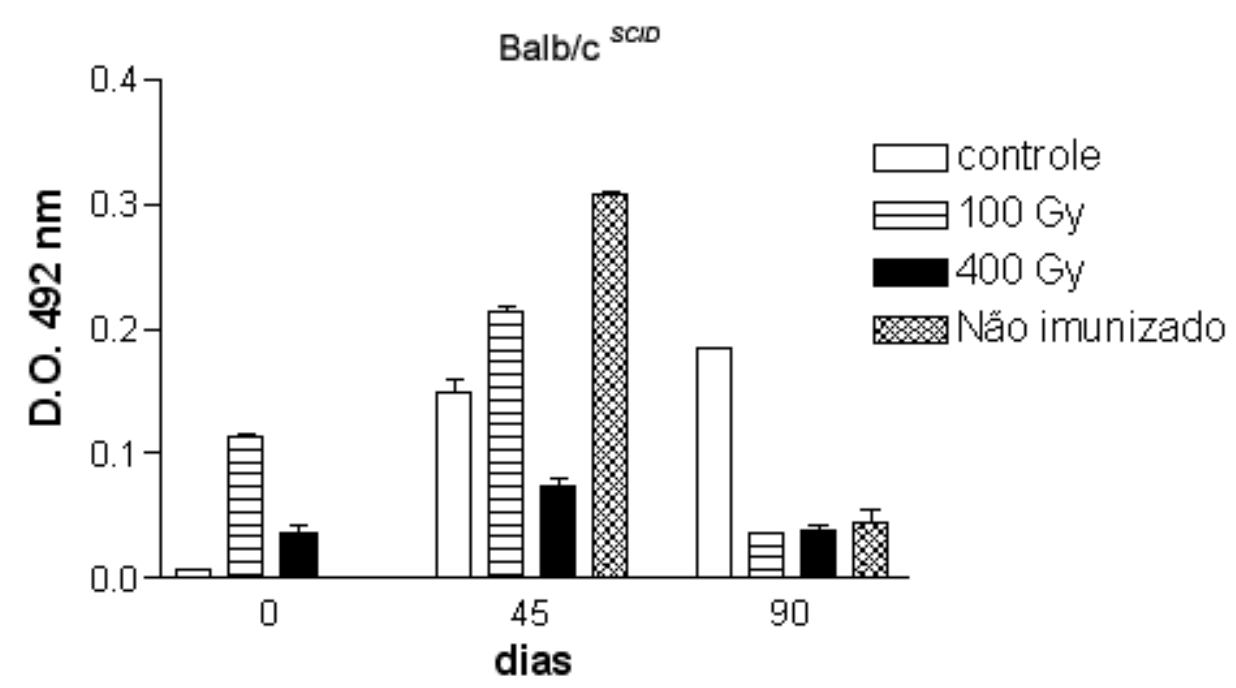

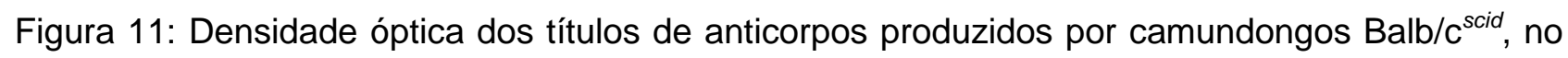
dia zero (primeira dose de imunização), dia 45 (desafio) e dia 90 (45 dias após a infecção) submetidos a três inóculos quinzenais de imunização, com $10^{6}$ parasitas/ $100 \mu \mathrm{L}$, com posterior desafio utilizando formas promastigotas de Leishmania amazonensis viáveis.

Os camundongos Balb/c $\mathrm{c}^{\text {scid }}$, uma linhagem modificada geneticamente a partir de outras linhagens de camundongos, não possuem, teoricamente, nenhuma das células do repertório necessário para o estabelecimento de uma resposta imunológica específica eficiente. Entretanto, os dados mostram a presença basal de moléculas que respondem à aplicação de anticorpos anti camundongo marcados com peroxidase. Entretanto, também neste caso não é possível estabelecer uma relação entre imunização, infecção e resposta imune específica.

Quando comparamos os títulos de anticorpos produzidos pelos diferentes grupos de camundongos, de todas as linhagens avaliadas, notamos que apenas os camundongos Balb/c imunizados com parasitas previamente selecionados com ambas as doses de radiação (100 e 400 Gy), produziram títulos significativos de anticorpos $(p<0.001)$, enquanto os camundongos $\mathrm{C} 57 / \mathrm{bl6}$ imunizados com parasitas préselecionados com a dose de $400 \mathrm{~Gy}$, produziram níveis intermediários de anticorpos $(p<0.05)$, que mantiveram-se após 45 dias do desafio.

Os grupos imunodeficientes não produziram anticorpos em nível significativo, descaracterizando uma resposta imunológica mediada por imunoglobulinas. 
4.5.2. Subclasses de Imunoglobulina G: A fim de compreender melhor o universo amplo das respostas imunológicas, foi realizado um segundo ensaio baseado na imunização e desafio de camundongos de diferentes linhagens, com 0 intuito de saber quais as subclasses de Imunoglobulina $G$ estariam envolvidas nas possíveis respostas imunes criadas por cada linhagem. A seguir, serão demonstradas nas figuras 12 à 15, o padrão de subclasses de lgG, dentre três, de maior ocorrência em doenças relacionadas à patógenos.

\section{Balb/c}

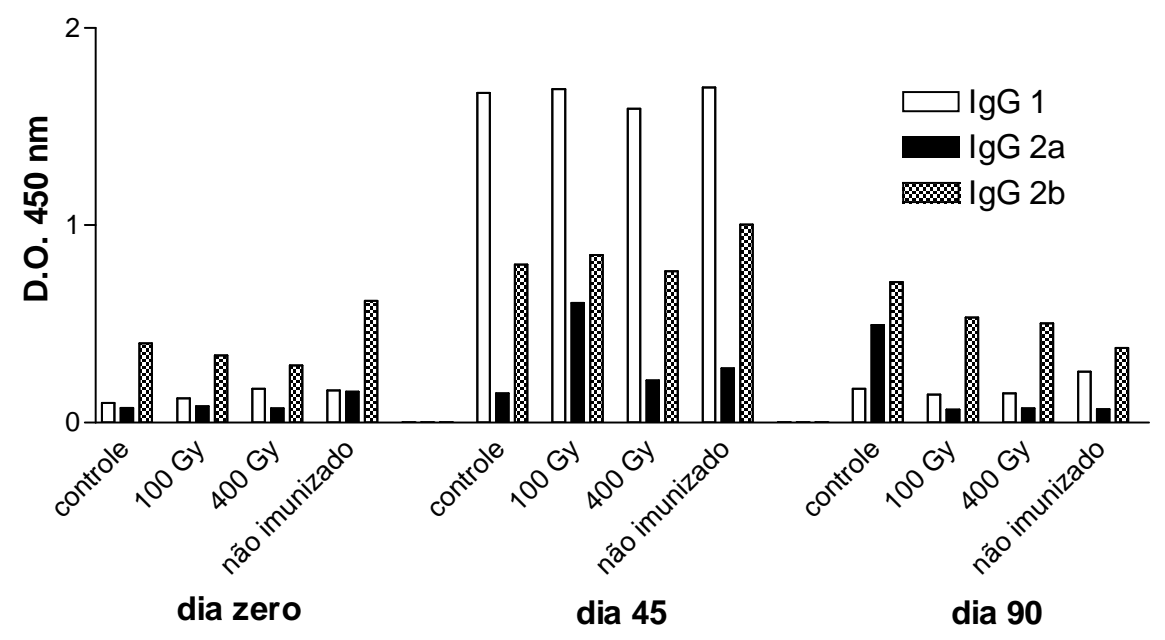

Figura 12: Densidade óptica dos títulos de três diferentes subclasses de Imunoglobulina G (IgG 1, $\lg$ (a e $\lg G 2 b$ ) produzidos por camundongos Balb/c no dia zero (primeira dose de imunização), dia 45 (desafio) e dia 90 (45 dias após a infecção) submetidos a três inóculos quinzenais de imunização, com $10^{6}$ parasitas/ $100 \mu \mathrm{L}$, com posterior desafio utilizando formas promastigotas de Leishmania amazonensis viáveis.

Camundongos Balb/c apresentaram após 15 dias da ultima dose de imunização, um aumento da Imunoglobulina $G$ de subclasse IgG 1. Em todos os grupos ocorreu um aumento considerável desta imunoglobulina em relação às demais. Ainda assim, os níveis de lgG 2b também apresentaram-se elevados, permanecendo por mais tempo acima dos demais. Ao passo que no final do experimento, eles encontravam-se com títulos bem superiores aos outros anticorpos. Vejamos agora, o que ocorreu com os camundongos menos susceptíveis à infecção por Leishmania amazonensis. 


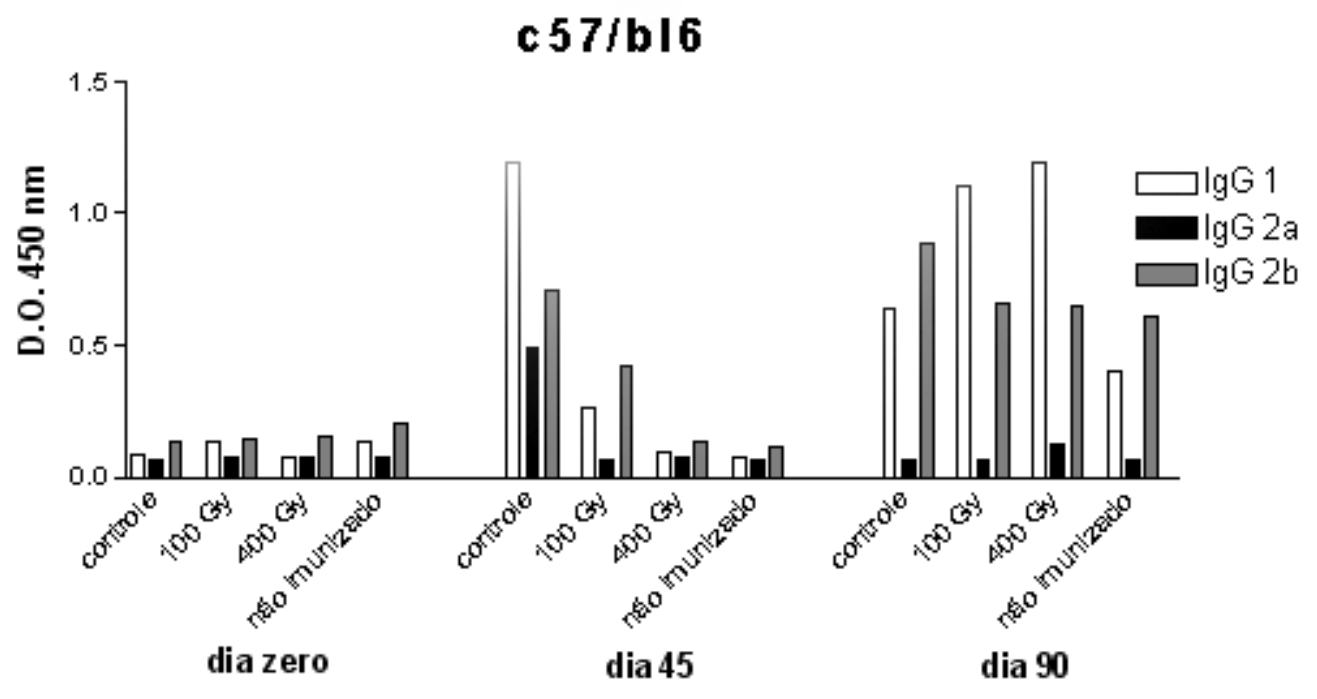

Figura 13: Densidade óptica dos títulos de três diferentes subclasses de Imunoglobulina G (IgG 1, $\lg$ 2a e $\lg G 2 b$ ) produzidos por camundongos c57/bl no dia zero (primeira dose de imunização), dia 45 (desafio) e dia 90 (45 dias após a infecção) submetidos a três inóculos quinzenais de imunização, com $10^{6}$ parasitas/ $100 \mu \mathrm{L}$, com posterior desafio utilizando formas promastigotas de Leishmania amazonensis viáveis.

Os camundongos c57/bl6j apresentaram uma ligeira elevação dos títulos de Imunoglobulinas $\mathrm{G}$ de subclasse 1 na quinzena após a última dose. Principalmente os camundongos do grupo denominado controle que receberam parasitas mortos com uma elevada dose de radiação, sem prévia seleção por doses mais baixas. Ao fim do experimento, os títulos de IgG 1 estavam aumentados em todos os grupos, entretanto no grupo controle, anteriormente com altas concentrações de anticorpos desta subclasse, agora é a IgG $2 \mathrm{~b}$ que se encontrou aumentada, não representando entretanto, diferença significativa aos títulos apresentados pelos outros grupos. A $\lg G 2 \mathrm{a}$, ao contrário, manteve-se em níveis bem menores durante o experimento. 


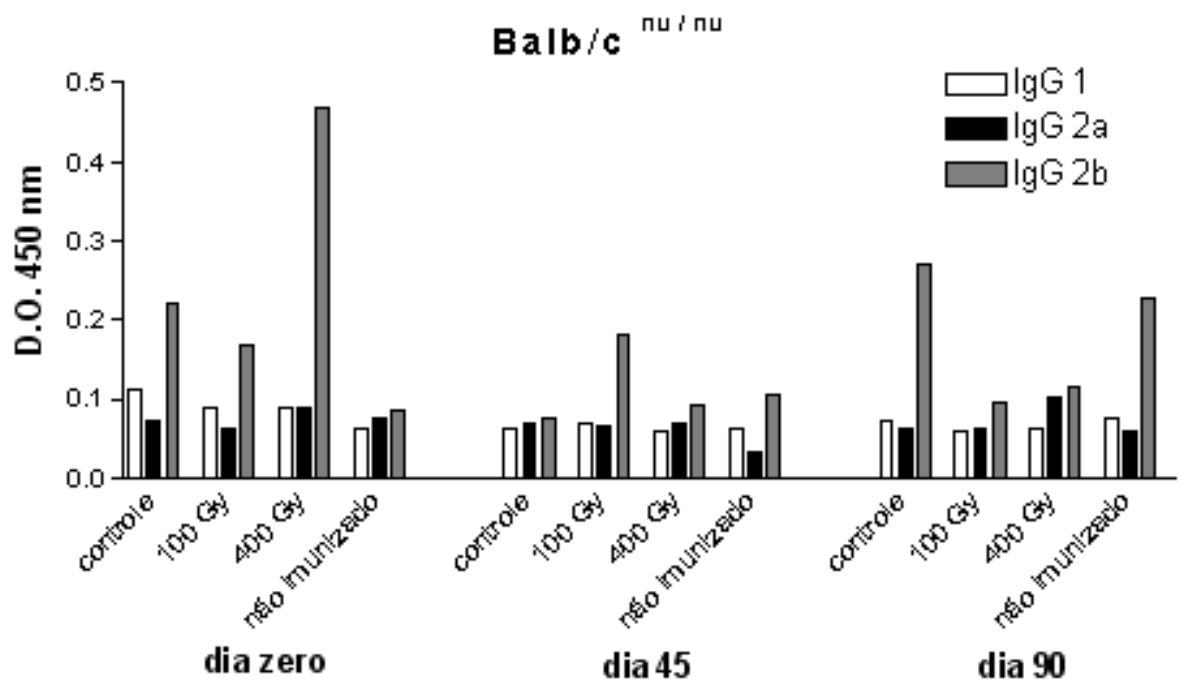

Figura 14: Densidade óptica dos títulos de três diferentes subclasses de Imunoglobulina G (IgG 1, $\lg \mathrm{G} 2 \mathrm{a}$ e $\lg \mathrm{G} 2 \mathrm{~b}$ ) produzidos por camundongos Balb/c $\mathrm{c}^{n / / n u}$ no dia zero (primeira dose de imunização), dia 45 (desafio) e dia 90 (45 dias após a infecção) submetidos a três inóculos quinzenais de imunização, com $10^{6}$ parasitas/ $100 \mu \mathrm{L}$, com posterior desafio utilizando formas promastigotas de Leishmania amazonensis viáveis.

Os camundongos nude, assim como já demonstrado nos resultados anteriores referentes a eles, não apresentaram elevação considerável dos títulos de anticorpos; e mesmo seu estado aumentado no início do experimento, não representa atividade humoral relevante, haja visto a densidade óptica produzida, muito próxima do basal para os camundongos providos de maquinaria imunológica completa. Este modelo apenas reforça a idéia da necessidade do Linfócitos T na capacidade imune de um organismo. 


\section{Balb/c SCID}

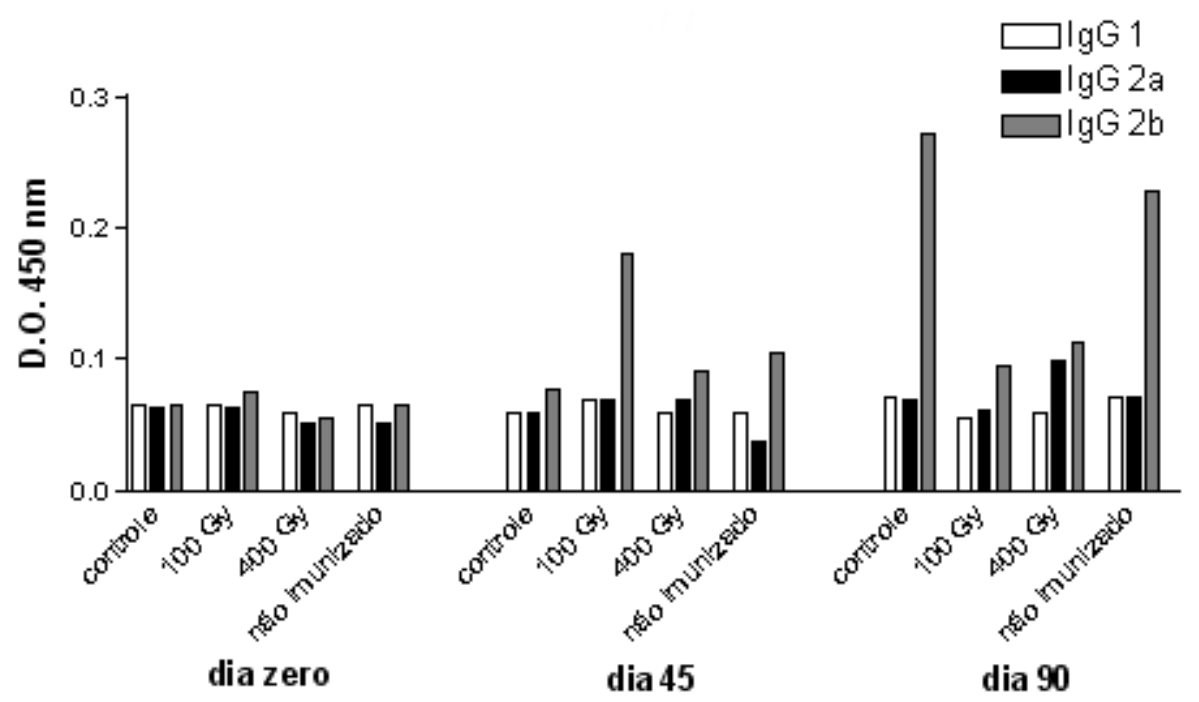

Figura 15: Densidade óptica dos títulos de três diferentes subclasses de Imunoglobulina G (IgG 1, $\lg 2$ a e $\lg$ 2b) produzidos por camundongos Balb/c ${ }^{\text {scid }}$ no dia zero (primeira dose de imunização), dia 45 (desafio) e dia 90 (45 dias após a infecção) submetidos a três inóculos quinzenais de imunização, com $10^{6}$ parasitas/ $100 \mu \mathrm{L}$, com posterior desafio utilizando formas promastigotas de Leishmania amazonensis viáveis.

Ao final dos ensaios com os camundongos Balb/c ${ }^{S C I D}$ pudemos notar a total ausência de produção de anticorpos em todos os tempos de análise do ensaio. Como ocorreu no grupo anterior, uma pequena elevação apresentada para IgG 2b nada tem de significância, uma vez que os títulos mais altos a que chegaram estes anticorpos são, na verdade, a metade do valor expresso pelos grupos com capacidade imune íntegra. Por não possuírem repertório celular de linfócitos $T$ e $B$, não há produção de anticorpos contra Leishmania spp. 
4.5.3. Análise macroscópica: Os dados apresentados a seguir referem-se à espessura das patas do camundongos referidos até o momento, e refletem o aparecimento, ou não, de lesão ulcerosa, característica da infecção por Leishmania amazonensis. Para tanto, foram realizadas medições periódicas das patas infectadas com parasitas viáveis, e comparadas com medições realizadas na pata oposta, não infectada.

\section{Balb/c}
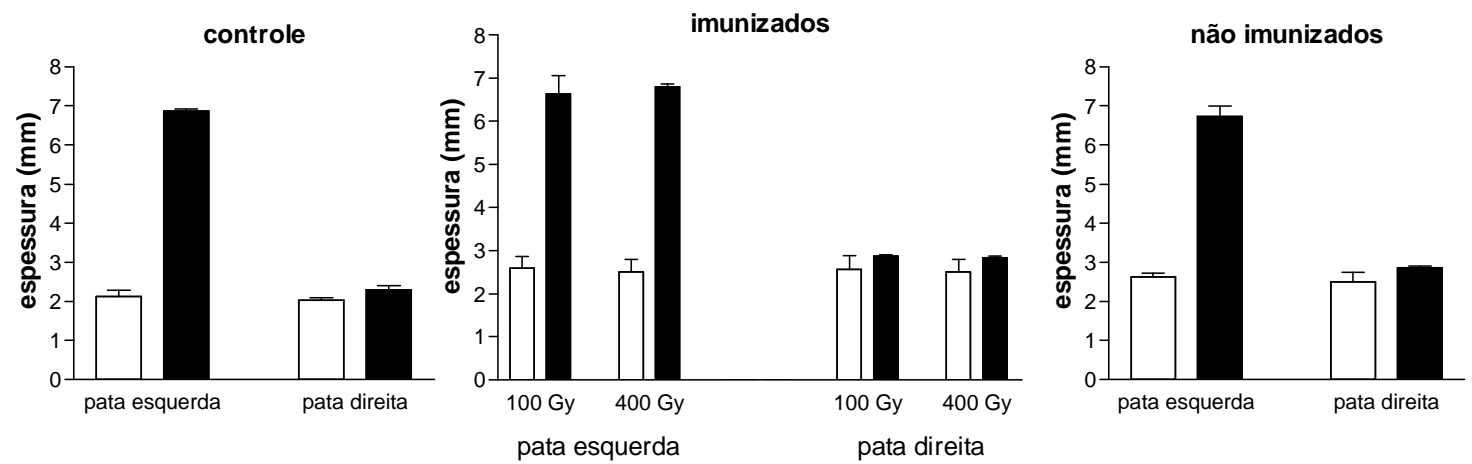

Figura 16: Espessura em milímetros das patas traseiras de camundongos Balb/c, no dia do desafio com formas viáveis de promastigotas de L. amazonensis (barras vazadas) e 45 dias após a infecção (barras cheias). A medição da espessura foi realizada no sentido dorso-ventral, com auxílio de um paquímetro analógico de precisão (MITUTOYO ${ }^{\circledR}$ ).

Os camundongos Balb/c apresentaram um aumento relevante e significativo do volume da pata traseira esquerda, onde ocorreu o inóculo de $10^{6}$ formas promastigotas de Leishmania amazonensis viáveis, concentradas em cem microlitros de meio de cultura HBSS, utilizado em diferentes experimentos deste trabalho, inclusive nos ensaios referentes à imunização. A primeira medição foi realizada no dia do desafio (dia 45) e acompanhada até o final do experimento. Os resultados mostram a comparação entre a data inicial e final das medições. Todos os grupos infectados, imunizados ou não, desenvolveram uma lesão exacerbada, compatível com a infecção natural da doença. $O$ volume final da pata infectada aumentou em mais de duas vezes durante o período de observação. Por outro lado, as patas utilizadas no controle demonstraram uma alteração discreta, resultado do crescimento natural dos animais. 


\section{c57/bl6}
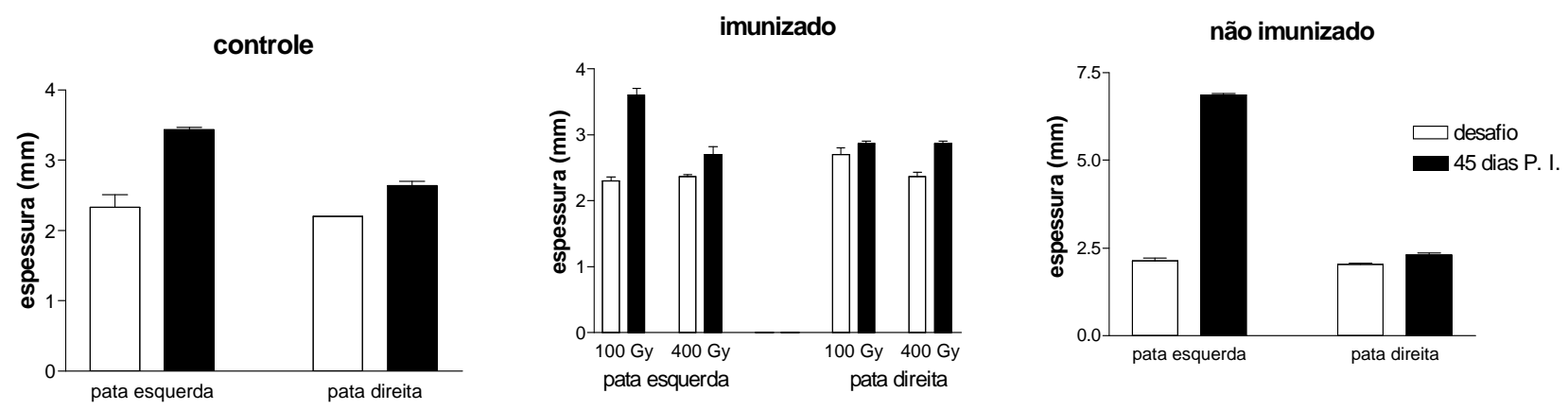

Figura 17: Espessura em milímetros das patas traseiras de camundongos c57/bl6, no dia do desafio com formas viáveis de promastigotas de L. amazonensis (barras vazadas) e 45 dias após a infecção (barras cheias). A medição da espessura foi realizada no sentido dorso-ventral, com auxílio de um paquímetro analógico de precisão (MITUTOYO ${ }^{\circledR}$ ).

Também nos camundongos c57/bl6 ocorreu aumento significativo das patas inoculadas com parasitas viáveis, independentemente da realização da imunização prévia O volume final das patas infectadas chegou a quase três vezes o seu tamanho, com aparecimento de lesões ulcerosas e autolimitadas, compatível com a infecção natural. Já as patas do lado oposto, não sofreram qualquer alteração em seu volume que possa ser relacionado com a doença.

\section{Balb/c ${ }^{\text {nu/nu }}$}
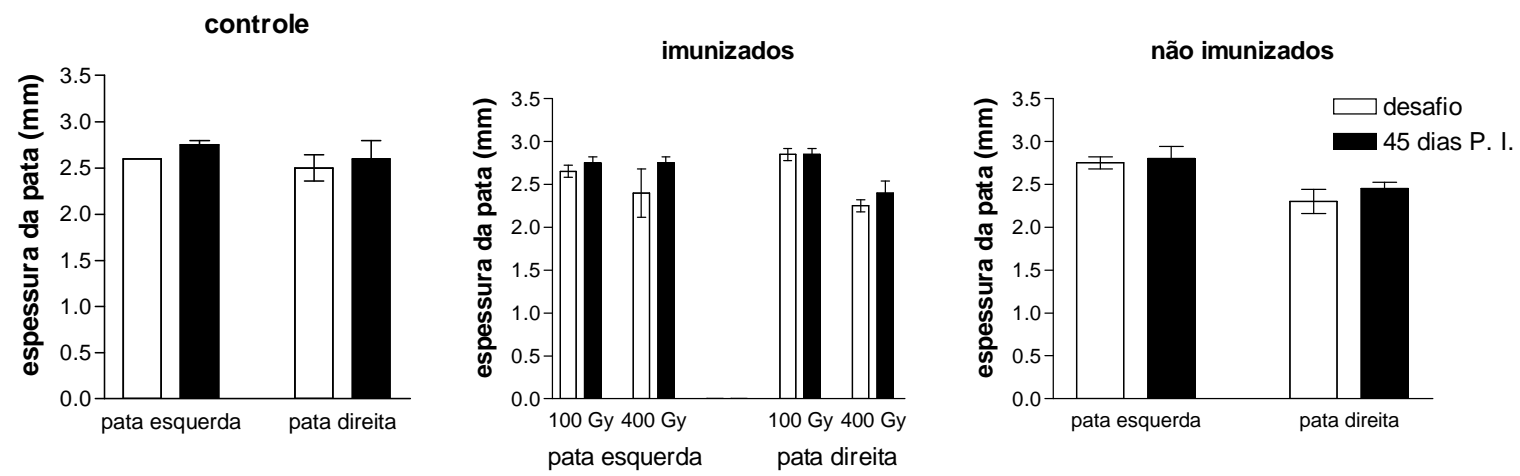

Figura 18: Espessura em milímetros das patas traseiras de camundongos Balb/c ${ }^{\text {nu/nu }}$, no dia do desafio com formas viáveis de promastigotas de $L$. amazonensis (barras vazadas) e 45 dias após a infecção (barras cheias). A medição da espessura foi realizada no sentido dorso-ventral, com auxílio de um paquímetro analógico de precisão $\left(\right.$ MITUTOYO $\left.{ }^{\circledR}\right)$. 
Os camundongos Balb/c ${ }^{n u / n u}$, de nenhum grupo, apresentaram aparecimento de lesão ou aumento da pata infectada, que pudessem estar relacionadas com a doença em estudo.

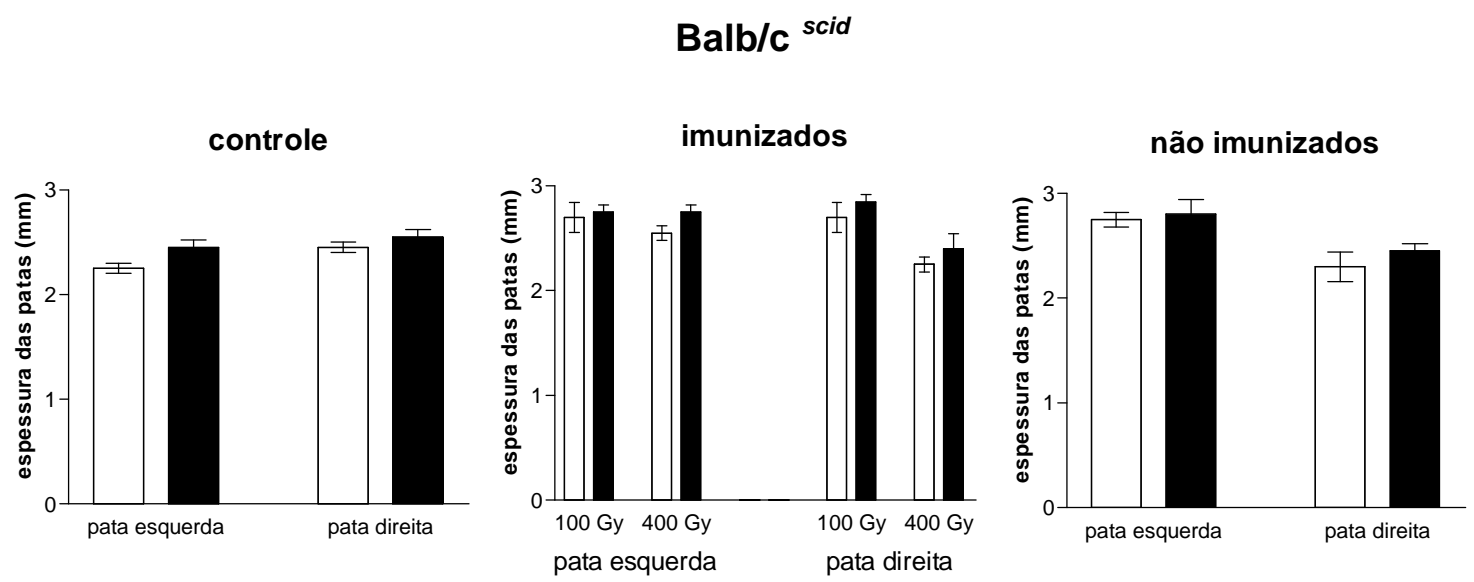

Figura 19: Espessura em milímetros das patas traseiras de camundongos Balb/c $\mathrm{c}^{\text {scid }}$, no dia do desafio com formas viáveis de promastigotas de L. amazonensis (barras vazadas) e 45 dias após a infecção (barras cheias). A medição da espessura da pata foi realizada no sentido dorso-ventral, com auxílio de um paquímetro analógico de precisão (MITUTOYO ${ }^{\circledR}$ ).

Assim como o ocorrido no grupo anterior, os camundongos Balb/c $\mathrm{c}^{\text {scid }}$ não apresentaram o aparecimento de lesão, ou aumento do volume da pata que possa estar associado à infecção por Leishmania amazonensis. Estudos mais aprofundados sobre 0 micro ambiente em questão talvez permitisse conclusões mais precisas sobre desenrolar da doença.

Quando feita a análise de significância do aumento relativo das patas traseiras dos camundongos dos diferentes grupos, notou-se que apenas os camundongos Balb/c, de todos os grupos, e os camundongos c57/bl6, não imunizados, respoderam com aumento significativo das patas $(p<0.05)$. Todos os outros grupos tiveram um aumento não significativo, ocorrido apenas pelo crescimento natural dos animais. 
4.5.4. Reação em Cadeia da Polimerase: $O$ material genético extraído das patas infectadas e não infectadas, dos camundongos utilizados nos ensaios de imunização, foi amplificado por PCR e analisado em um gel de Agarose 1\%. Os resultados demonstram a presença de rDNA compatível com o do Gênero Leishmania spp., em todas as amostras retiradas de camundongos imunizados ou não, com posterior desafio com parasitas viáveis, conforme observado nos resultados anteriores. A figura apresenta positividade para todas as amostras. Controle positivo: material retirado de pata de camundongo apenas infectado com formas promastigotas de Leishmania amazonensis. Controle negativo: pata de camundongo Balb/c não imunizado e não infectado.

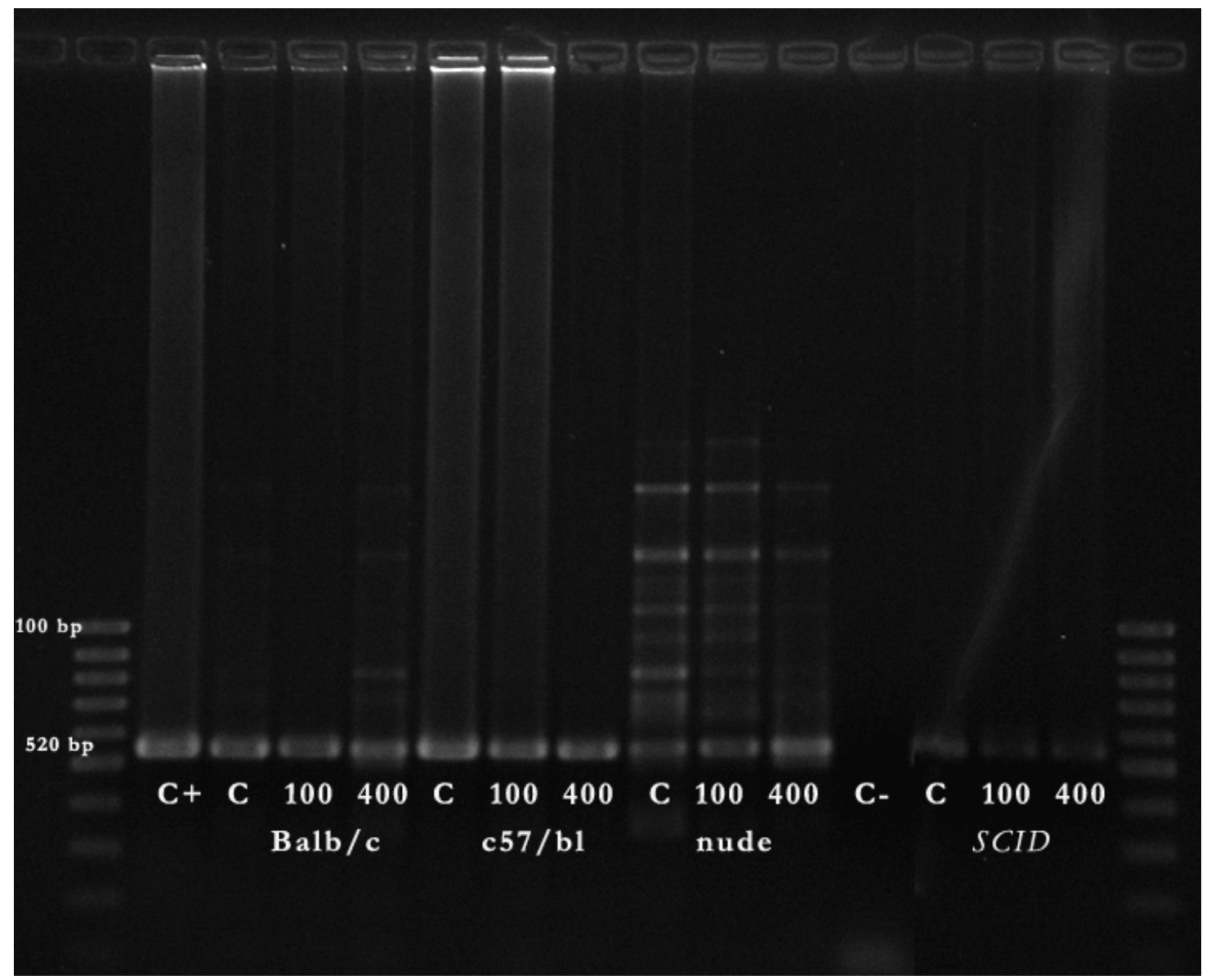

Figura 20: Eletroforese em gel de agarose de uma reação de Polimerase Chain Reaction (PCR), apresentando banda para caracterização de material genético ribossomal de protozoários do Gênero Leishmania spp., de 520 pares de base (520 bp). A figura mostra a presença de banda para todas as amostras pesquisadas, exceto para o controle negativo (C-). A banda marcada com $\mathrm{C}+$ representa o controle positivo da reação. 


\section{DISCUSSÃO}

Discutiremos a partir deste ponto a dinâmica dos efeitos da radiação gama sobre as formas promastigotas da Leishmania amazonensis, um organismo unicelular, capaz de mobilizar todo um sistema complexo, de moléculas e células de seu hospedeiro, a favor de sua sobrevivência.

Formas promastigotas de Leishmania amazonensis cultivadas em meio RPMI 1640 multiplicam-se rapidamente durante alguns dias, estabilizando a concentração de parasitas na colônia por um breve período (em torno de dois dias), quando então começa a declinar devido a fatores limitantes como, por exemplo, a falta de nutrientes do meio (PINTO-DA-SILVA et al., 2002).

Sabe-se que estas formas possuem diferentes estágios de desenvolvimento que se iniciam com a forma promastigota procíclica, no qual os parasitas apresentam-se aderidos às células da luz do intestino do inseto vetor alimentando-se e reproduzindo-se assexuadamente em crescimento logarítmico. Ao passo que a quantidade de nutrientes disponíveis começa a decair, entre outros fatores inerentes ao vetor, o protozoário inicia uma modificação de sua morfologia e metabolismo, passando por três curtos estágios de metamorfose, denominados respectivamente por: nectomonadas, haptomonadas e paramastgotas. Passados estes estágios as formas promastigotas encontram-se menores, mais afiladas, com um flagelo mais largo e com maior mobilidade (ZAKAl et al., 1997; MUSKUS et al., 2002); momento este em que os parasitas deixam o intestino do inseto e dirigem-se para a probóscida do inseto, onde mantém-se envolvidos por um gel de proteofosfoglicano (PSG). Nesta última etapa de transformação os parasitas estão prontos para infectar um hospedeiro vertebrado e dar continuidade ao seu ciclo evolutivo. Estas são as formas promastigotas metacíclicas (MAHONEY et al., 1999; ROGERS et al., ,2001).

Dá-se o nome de metaciclogênese à este processo de transformação de um estágio ao outro, sendo que ocorre por meio de reações químicas extremamente elaboradas, como a alteração da camada de açúcares que recobrem toda a membrana celular do protozoário (RALTON et al., 2002), que o protegerão quando ocorrer sua entrada no hospedeiro e uma conseqüente ativação dos componentes imunológicos, entre eles as moléculas do Sistema Complemento, evitando sua lise (DOMíNGUEZ et al., 2002). 
O que se sugere, portanto, é que o estágio estacionário no qual se encontram os parasitas, antes de diminuir sua concentração na cultura, seria a correspondente ao estágio metacíclico, no qual os protozoários não se dividem, e estão preparadas para infectar o hospedeiro vertebrado (SARTORI et al., 1997). Sabendo disso, e baseando-se em dados encontrados em outros experimentos (BONETTI et al., 2002) resolveu-se avaliar qual seria a menor dose de radiação ionizante capaz de selecionar na cultura, somente Leishmania amazonensis neste estágio de desenvolvimento. Para tanto foi feita primeiramente uma cultura de parasitas não irradiados a fim de saber qual o tempo natural para ocorrer este processo.

Os dados encontrados em nossos experimentos corroboram os achados da literatura, mostrando que, nos quatro primeiros dias de cultura, os parasitas cresceram exponencialmente atingindo $4,4 \times 10^{7}$ parasitas $/ \mathrm{ml}$ (em torno de 20 vezes mais parasitas). Nos quinto e sexto dias houve uma estabilização do crescimento de parasitas destas culturas, sugerindo que ocorreu uma transformação nestes parasitas, da forma procíclica para metacíclica. Este fenômeno já havia sido observado por LEMESRE e colaboradores (1988).

Após a determinação da possível existência de duas populações distintas em uma mesma cultura, deu-se início aos ensaios de irradiação das formas promastigotas de Leishmania amazonensis, crescidas em RPMI 1640 e mantidas por 24 horas, antes do processo de irradiação, em meio de cultura HBSS, que mimetiza os aminoácidos e outros nutrientes presentes na luz do intestino do inseto. Esta passagem foi realizada para estabilizar as duas populações da cultura em seus estágios de transformação (pró e metacíclicas).

O processo de irradiação foi realizado como ferramenta para selecionar as formas metacíclicas desta cultura, partindo do princípio preconizado em 1906, pelos radiobiologistas franceses Bergonie e Tribondeau, em que células em divisão, ou diferenciação, são mais radiossensíveis em relação a células em estágio estacionário (Lei de Bergonie \& Tribondeau) (HALL, 2000). Para provar a capacidade seletiva deste mecanismo, foram realizados alguns testes comprobatórios.

A utilização de radiação ionizante como ferramenta para alteração estrutural, atenuação ou seleção de formas infectantes não é uma novidade. Diferentes grupos de pesquisa ao redor do mundo lançam mão desta tecnologia, com resultados satisfatórios para diferentes parasitas como, por exemplo, Neospora caninum (RAMAMOORTHY et al., 2006), Clonorchis sinensis (QUAN et al., 2005), Schistosoma mansoni (el-GAWASHI \& 
MOAWAD, 2003), Cryptosporidium parvum (JENKINS et al., 2004), Euglena gracilis (HAYASHI et al., 2004), Toxoplasma gondii (HIRAMOTO et al., 2002), Trypanosoma rangeli (GOMES et al., 2002)Leishmania major (RIVIER, 1993) e Trypanosoma cruzi (HANSON et al., 1976), para citar alguns.

O primeiro ensaio realizado foi a contagem dos parasitas, antes e após o processo de irradiação. Decorridas 24 horas da passagem da cultura para o meio HBSS, contou-se o número de parasitas em câmara de Neubauer, e estabeleceu-se a concentração de parasitas em $6 \times 10^{6} / \mathrm{mL}$. Os parasitas em cultura foram irradiados com diferentes doses, variando de 25 a $400 \mathrm{~Gy}$, e estabeleceu-se nova contagem em cada um dos tubos irradiados: os resultados encontrados mostraram que na dose de 25 Gy, houve já uma diminuição da concentração de parasitas em torno de $40 \%$, com uma diminuição progressiva, que continuou sendo observada nas doses de 50, 200 e 400 Gy. Porém na dose de 100 Gy ocorreu uma diminuição mais branda da concentração destes parasitas, dentro da faixa de desvio. Em um estudo preliminar (BONETTI et al., 2000), já havia sido observado que, com as doses de 50 e100 Gy, estes protozoários tinham sua capacidade de sintetizar proteínas e ácido nucléico pouco afetadas, comparando com outras doses.

Com relação à capacidade de infecção destes parasitas, em ensaios in vitro, o fenômeno observado foi uma maior capacidade de parasitas irradiados com 400 Gy, em relação à concentração de Leishmania na cultura. Quando se compara os gráficos (Figuras 4 e 5), observa-se que número de parasitas sobreviventes após o processo de irradiação com a dose 400 Gy é bem menor que o número encontrado nas culturas irradiadas com outras doses, entretanto a porcentagem de células infectadas por eles é igual ou maior do que a encontrada nas outras culturas. Resultados semelhantes já haviam sido observados por ZAKAI e colaboradores (1997), utilizando quatro diferentes espécies de Leishmania spp., inclusive do subgênero Leishmania.

A sugestão de que com esta dose de radiação conseguiu-se estabelecer uma colônia de parasitas predominantemente metacíclicos, foi analisada com ensaios de lise destes parasitas irradiados, por componentes do Sistema Complemento, um conjunto de proteínas do Sistema Imunológico Inato, encontrado no soro de diferentes espécies de mamíferos. O ensaio realizado consiste da incubação dos parasitas com diferentes concentrações de soro de cobaio (guinea-pig) não inativado, rico nestas proteínas (NUNES et al., 1997). O que se notou foi que em ambas as concentrações utilizadas, $10 \%$ e $20 \%$, os efeitos sobre o número de parasitas afetados foi similar, motivo este que levou a utilização da concentração de $10 \%$ nos experimentos que se seguiram (Figura 6). Esta 
metodologia é uma das utilizadas normalmente em ensaios de metaciclogênese (BRITTINGHAM et al., 1995), e destaca-se por representar o mecanismo de destruição empregado por diferentes vertebrados como forma primeira de ataque e destruição de dos mais variados patógenos, incluindo os diferentes Gêneros de tripanosomatídeos (DOMINGUÉZ et al., 2002).

Em uma resposta imunológica convencional, não suprimida, as proteínas do Sistema Complemento agem sobre os parasitas, ligando-se às moléculas contidas em sua membrana celular, formando uma estrutura denominada Complexo de Ataque à Membrana, que perfuram a membrana do protozoário levando-o à destruição. $\mathrm{Na}$ leishmaniose esta ação se dá com o acionamento da cascata pela via alternativa (C3), diretamente pela ação das moléculas principais de superfície do patógeno (NUNES \& RAMALHO-PINTO, 1996; SPÄT et al., 2003; LAURENTI et al., 2004).

Durante a infecção natural de Leishmania spp. em hospedeiros vertebrados, as milhares de unidade de Lipofosfoglicanos (LPG), ancorados à membrana celular por meio de estruturas intracelulares denominadas glicofosfatidilinositol (GPI), ou lançadas ao micro ambiente, são fatores determinantes de sobrevivência para o protozoário, bem como, as glicoproteínas gp63, ambos considerados os maiores fatores imunogênicos e de virulência do patógeno (McGWIRE et al., 2002). As moléculas de LPG são espécie específicas e garantem maior resistência não só às ações das proteínas do Complemento, mas também aos fagócitos mononucleares, como o Macrófago, por exemplo. Nas formas promastigotas metacíclicas o LPG possui um maior número de unidades nas cadeias de açúcar, além de radicais que se ligam a eles, como os arabinóis (WILSON et al., 1999; SOARES et al., 2002).

Assim sendo, os parasitas que sobreviveram à irradiação com a dose de 400 Gy de radiação ionizante, e também ao ataque das proteínas do Complemento, possuem mecanismos que os protegem, assim como ocorre com o parasita não irradiado, em fase metacíclica.

Para uma melhor compreensão dos fenômenos ocorridos com as formas promastigotas pela ação da radiação ionizante, recorremos às imagens de Microscopia Eletrônica, corriqueiramente utilizada para observação de estruturas celulares de diferentes tipos, entre elas de microorganismos patogênicos. Interessantes resultados já foram obtidos com diferentes patógenos, entre os quais: Trypanosoma cruzi (MORTARA et al., 2005), Leishmania spp. (RASMUSSON \& DESCOTEAUX, 2004), Trypanosoma brucei (FIELD et al., 2004), Cryptosporidium parvum (PETRY, 2004), Trichomonas spp. 
(BENCHIMOL, 2004), Giardia lamblia (de SOUZA et al, 2004), Toxoplasma gondii e Plasmodium spp. (BINDER \& KIM, 2004).

Em nosso trabalho, a análise utilizando Microscopia Eletrônica, revelou que, em parasitas não irradiados, as moléculas do Complemento acarretam lise celular com extravasamento de material citoplasmático, e degradação do flagelo, implicando em perda da viabilidade celular apenas das células em fase procíclica, mantendo íntegras as células metacíclicas. No que diz respeito às formas promastigotas de Leishmania amazonensis irradiadas com uma dose de 100 Gy de radiação gama $\left({ }^{60} \mathrm{Co}\right)$, estas perdem a sua forma, por uma destruição dos microtúbulos que formam o arcabouço celular do parasita, mantendo porém, o metabolismo celular intacto, conforme demonstrado em experimentos anteriores; já quando submetidos à ação das moléculas do Complemento, após a irradiação, a maior parte dos protozoários da cultura sofrem os mesmos efeitos danosos que ocorreram no grupo não irradiado, o que nos leva a acreditar que na cultura irradiada com esta dose não ocorre uma seleção dos parasitas resistentes.

Esta observação reforça a idéia que doses menores que 400 Gy apenas destroem os parasitas que se encontram, naquele momento, em divisão celular, ou que estejam em uma fase pré-mitótica de alinhamento de nucléolos, não sendo estas portanto, doses ideais para serem utilizadas como ferramenta de seleção.

Com relação aos achados da irradiação com a dose de 400 Gy, os parasitas estão com algumas alterações de suas características iniciais como por exemplo a ausência de flagelo e alteração da forma afilada, peculiar das formas promastigotas. Entretanto, não se observa a destruição da membrana celular, ou sinais de destruição significativos, que possam sugerir perda de viabilidade. No que se refere aos parasitas irradiados e submetidos à posterior incubação com soro contendo as proteínas do Complemento, nada se nota de alteração maior. Comparadas as imagens de ambas culturas, os parasitas apresentam características semelhantes. Esta observação salienta, ainda mais, a idéia da seleção de formas metacíclicas de formas promastigotas de Leishmania amazonensis em cultura.

A estrutura da membrana deve futuramente ser submetida a uma análise mais cuidadosa para determinar sua composição química, podendo enriquecer os conhecimentos sobre a eficácia desta metodologia envolvendo a irradiação como forma de selecionar parasitas com maior poder infectante em culturas de formas promastigotas de Leishmania amazonensis, abrindo caminhos para um vasto campo de pesquisa sobre um assunto tão interessante. 
Terminada esta etapa dos ensaios estamos convencidos da funcionalidade do uso de radiação ionizante como ferramenta de seleção de parasitas. Entretanto ainda nos faltava entender como estes parasitas se comportam quando são introduzidos em organismos vivos, com uma resposta imunológica contendo todos os seus elementos, e não apenas um deles.

Para tanto, o outro estudo realizado ao longo deste trabalho foi a imunização de camundongos de diferentes linhagens, utilizando as formas promastigotas de Leishmania amazonensis, irradiadas, e submetidas, ou não, à incubação com as proteínas do Complemento.

Foram escolhidos quatro diferentes linhagens de camundongos. São elas: o C57/bl, que possui uma capacidade de desenvolver uma resposta celular tardia e reverter a doença infecciosa (MORA et al., 1999); o Balb/c, camundongo com resposta imune Th2 (mediada por Imunoglobulinas), que não reverte o quadro de infecção por Leishmania (PINTO et al., 2003), Balb/c ${ }^{\text {nu/nu }}$ (nude), linhagem sem o Timo, órgão de extrema importância na maturação de linfócitos $T$, e portanto com Resposta Imune específica deficiente (TERABE et al., 1998) e Balb/c ${ }^{S C I D}$, uma linhagem com alterações celulares bastante significativas, isto é, ausência de Linfócitos $T$ e $B$, e portanto, sem possibilidade de elaborar resposta imune específica, denominada como Imunodeficiência Severa Combinada $(S C I D$, é a sigla em inglês para esta terminologia) (TERABE et al., 1999; DAVIES \& STANLEY, 2003).

Antes de darmos continuidade à discussão, façamos um largo parênteses para entendermos alguns fatores que nos levaram à escolha destes modelos em nossa pesquisa.

O uso de modelos manipulados nos dão um bom entendimento sobre alguns mecanismos que não podem ser reproduzidos in vitro, e tão pouco em seres humanos; porém, não devem ser considerados como fidedignos das ocorrências naturais, uma vez que são linhagens isogênicas, e respondem de maneira semelhante na grande maioria das vezes, diminuindo a nossa percepção do entendimento geral de uma situação em populações heterogêneas. Entretanto, o uso destes modelos são uma realidade para diferentes doenças associadas ou não a parasitas, com resultados bastante satisfatórios e elucidativos. Pretendemos assim, dar nossa contribuição à ciência com um passo inicial de seu uso sobre as diferentes possibilidades de desenvolvimento desta doença espectral, com acometimentos diversos, que variam de simples lesões autolimitadas com propensão à cura espontânea, até uma doença sistêmica com índices elevados de óbito 
em alguns indivíduos. em leishmaniose.

O que se observou inicialmente nos resultados encontrados no experimento de imunização dos modelos, foi uma resposta com altos títulos de anticorpos nos camundongos Balb/c, tanto no dia do desafio, após quinze dias da última dose de imunização, quanto ao final de 90 dias (45 dias após o desafio), sendo os títulos mais elevados aqueles produzidos por parasitas irradiados, tanto com a dose de 100 Gy, quanto com a de 400 Gy após a imunização, com permanência, ainda que com títulos menos elevados, naqueles imunizados com parasitas irradiados com a dose de 400 Gy. Os animais denominados controle, cujos parasitas utilizados na imunização foram mortos com uma dose de 2 KGy de radiação sem prévia seleção, responderam após 45 dias do desafio com títulos equivalentes àqueles que foram apenas infectados (Figura 8). Quanto às classes de imunoglobulina $\mathrm{G}$ resultante, notamos prevalência do isotipo IgG1 após a imunização de todos os grupos, e $\lg \mathrm{2b}$ ao final de 45 dias após o desafio. Ambos isotipos são característicos de uma resposta do tipo Th2, desencadeada pelo aumento da citocinas IL-4 e IL-10, resultando na susceptibilidade dos animais à infecção e conseqüente aparecimento de lesões ulcerosas nas patas inoculadas e aumento considerável do volume da pata em relação à não infectada, tal qual ocorre durante a infecção natural (Figuras 12 e 15), como já descrito por outros autores (NASHED et al., 2000). Podemos afirmar que os parasitas selecionados e mortos pela radiação, não conferem a curto prazo, um estímulo à um padrão de resposta imune protetor, entretanto, a imunização por si só, não leva ao aparecimento de lesões.

Os camundongos da linhagem C57/bl apresentaram produção de anticorpos após o período de imunização com diminuição progressiva ao longo dos dias que se sucederam (Figura 9). Os títulos relativamente baixos de Imunoglobulinas produzidos por estes camundongos foram acompanhados de lesões pouco disseminadas (Figura 16). Os títulos mais elevados ocorreram apenas nos animais imunizados com parasitas previamente selecionados com a dose de 400 Gy de radiação ionizante, o que demonstra ter havido maior reconhecimento do Antígeno pelas células do Sistema Imune Inato, com eficiente apresentação deste Antígeno. No que diz respeito ao padrão de isotipos de Imunoglobulinas, ocorreu uma maior produção de $\lg G 1$ e $\lg G$ 2b, como ocorreu no modelo anterior (Figura 13). Ainda que para outros modelos de infecção por Leishmania spp. Estes animais tenham capacidade de resolução da infecção, outros autores já demonstraram não ocorrer o mesmo com a Leishmania amazonensis, sendo que estes animais tendem ao desenvolvimento da doença (MAIOLI et al., 2004). 
Por outro lado, o modelo nude apresentou ínfima produção de Imunoglobulinas, provavelmente inespecíficas, produzidas por uma população celular de Linfócitos B Timo independentes, uma vez que este modelo é desprovido de tal órgão, importante para a seleção e maturação de Linfócitos $T$, essencial para o desenvolvimento de uma resposta imunológica eficiente. Entretanto, também não foi observado aparecimento de lesão cutânea na pata inoculada com parasitas não irradiados, tendo havido apenas um ligeiro aumento do seu volume (Figura 18). Outros grupos de pesquisa que induziram infecção em camundongos deficientes de células $T$ mostram a importância desta célula na formação destas úlceras (TERABE et al., 1999). O padrão de subclasse IgG 2b apresentado nos resultados (Figura 14), apesar de estar mais elevado, não representa necessariamente ter sido induzido pela imunização ou infecção, devido às baixas concentrações quando comparamos com os outros modelos.

O quarto modelo analisado, a linhagem SCID, também apresentou uma titulação ínfima e anticorpos resultantes apenas de um background do ensaio (Figura 11). E apesar de outros autores relatarem a presença de granulomas associados à infecção por Leishmania amazonensis (TERABE et al., 1999), em nosso estudo isto não ocorreu (Figura 19), provavelmente pelo fato dos parasitas estarem mortos e não oferecerem resistência às células do Sistema inato de defesa.

Com o intuito de verificar se havia presença de parasitas, mesmo nos animais imunodeficientes, no local da infecção, foi realizado um PCR utilizando um primer específico para o Gênero Leishmania spp., que resultou em positividade em todas as amostras (Figura 20). Isto comprova, ainda mais, a atuação das células efetoras da respostas imune específica no curso da instalação da infecção por estes parasitas.

Desta forma, concluímos o trabalho tendo clara a possibilidade da utilização da radiação gama como ferramenta para a seleção de formas promastigotas metacíclicas, em culturas axênicas, abrindo as portas para futuros trabalhos neste sentido. 


\section{CONCLUSÕES}

Conclui-se ao final deste trabalho que:

A dose de 400 Gy de radiação gama, produzida em fonte de ${ }^{60} \mathrm{Co}$ é uma eficiente ferramenta para a seleção de formas metacíclicas de Leishmania amazonensis, sendo que as doses de 25, 50, 100 e 200 Gy não têm este poder.

Formas promastigotas procíclicas não resistem ao ataque das proteínas do Sistema Complemento, enquanto as formas metacíclicas não são destruídas por esta interação.

Parasitas em sua forma metacíclica sobrevivem à radiação, mantendo sua imunogenicidade e capacidade de infecção in vitro e in vivo.

Camundongos imunizados e desafiados com parasitas irradiados com as doses de 100 e 400 Gy produzem uma resposta imune com os mesmo padrões que o ocorrido na infecção natural, via picada do inseto.

Camundongos que não apresentaram sinais clínicos da infecção possuíam material genético dos parasitas, na pata infectada.

Estudos mais aprofundados sobre as características imunológicas dos modelos experimentais imunizados com estes parasitas contribuirão sobremaneira para o desenvolvimento de imunógenos eficientes, utilizando a radiação gama como ferramenta de seleção de parasitas infectante. 


\section{REFERÊNCIAS}

ALTAMIRANO-ENCISO A.J.; MARZOCHI M.C.; MOREIRA J.S.; SCHUBACH A.O.; MARZOCHI K.B. On the origin and spread of cutaneous and mucosal leishmaniasis, based on pre- and post- colombian historical source. História, Ciências, Saúde-Manguinhos, v. 10, n. 3, P. 852-82, 2003.

ÁLVAREZ-FORTES, E.; RUIZ-PÉREZ, L.M.; BOUILLAUD, F.; RIAL, E.; RIVAS, L. Expression and regulation of mitochondrial uncoupling protein 1 from brown adipose tissue in Leishmania major promastigotes. Molecular and Biochemical Parasitology, V. 93, n. 2, p. 191-202, 1998.

ANTOINE, J.C.; LANG, T.; PRINA, E.; COURRET, N.; HELLIO, R. H-2M molecules, like MHC class II molecules, are targeted to parasitophorous vacuoles of Leishmania infected macrophages and internalized by amastigotes of L. amazonensis and L. mexicana. Journal of Cell Science, v. 112, n. 15, p. 2559-2570, 1999.

ARAUJO SOARES R.M.; SANTOS, A.L.S.; BONALDO, M.C.; DE ANDRADE, A.F.B.; ALVIANO, C.S.; ANGLUSTER, J.; GOLDENBERG, S. Leishmania (Leishmania) amazonensis: differential expression of proteinases andcell-surface polypeptides in avirulent and virulent promastigotes. Experimental Parasitology, v.104, p. 104-112, 2003.

BARR, S.;D, GEDAMU, L. Role of peroxidoxins in Leishmania chagasi survival. Evidence of an enzymatic defense against nitrosative stress. Journal of Biological Chemistry, V. 278, N. 12, P. 10816-23, 2003.

BALANA-FOUCE, R.; REGUERA, R.M.; CUBRIA, J.C.; ORDONEZ, D. The pharmacology of leishmaniasis. General Pharmacology, v. 30, n. 4, p. 435-43, Review, 1998.

BECKER, I.; SALAIZA, N.; AGUIRRE, M.; DELGADO, J.; CARRILLO-CARRASCO, N.; 
KOBEH, L.G.; RUIZ, A.; CERVANTES, R.; TORREZ, A.P.; CABRERA, N.; GONZÁLEZ, A.; MALDONADO, C.; ISIBASI, A. Leishmania lipophosphoglycan (LPG) activates NK cells through Toll-Like receptors. Molecular and Biochemistry Parasitology, v. 130, p. 65-74, 2003.

BENCHIMOL, M. Trichomonas under Microscopy. Microscopy and Microanalysis, v. 10, p. 528-550, 2004.

EMILY M. BINDER, E.M.; KIM, K. Location, Location, Location: Trafficking and Function of Secreted Proteases of Toxoplasma and Plasmodium Traffic, v. 5, p. 914-924, 2004.

BOGDAN, C.; HOLLINGHOFF, M. How do protozoan parasites survive inside macrophages? Parasitology Today, v. 15, n. 1, p. 22-28,1999.

BONETTI, F.C.; ANDRADE, JR, H.F.; SPENCER, P.J.; NASCIMENTO, N. Ação da radiação ionizante sobre a morfologia, fisiologia e crescimento da Leishmania spp. In: V ENCONTRO NACIONAL DE APLICAÇÕES NUCLEARES, 18-25 Outubro, Rio de Janeiro. Anais... Rio de Janeiro, p. 361, 2000.

BONETTI, F.C.; HIRAMOTO, R.M.; PAIVA, B.; ANDRADE Jr, H.F.; NASCIMENTO, N. Aspectos morfológicos da Leishmania amazonensis submetida à ação da radiação ionizante. In: VI ENCONTRO NACIONAL DEE APLICAÇÕES NUCLEARES. Anais do VI ENCONTRO NACIONAL DE APLICAÇÕES NUCLEARES, Rio de Janeiro, 2002.

BONETTI, F.C.; ANDRADE JR, H.F.; NASCIMENTO, N. Metacyclic promastigotes of Leishmania amazonensis selection using gamma irradiation. In: Annals of INTERNATIONAL NUCLEAR ATLANTIC CONFERENCE - INAC. Santos, SP, Brazil, August 28 to September 2, 2005.

BORBOREMA, S.E.T. Biodistribuição do Antimoniato de Meglumina em animais sadios e infectados com Leishmania (L.) chagasi. Dissertação (Mestrado em Tecnologia Nuclear) - Instituto de Pesquisas Energéticas E Nucleares, Conselho Nacional de Desenvolvimento Científico e Tecnológico, 2005. 
BORJA-CABRERA, G.P.; MENDES, A.C.; SOUZA, E.P.; OKADA, L. Y.H; TRIVELLATO F.A.A.; KAWASAKI, J.K.; COSTA, A.C.; REIS, A.B.; GENARO, O.; BATISTA, L.M.M.; PALYINIK, M.; PALATINIK DE SOUZA, C.B. Effective immunotherapy against canine visceral leishmaniasis with the FML-vaccine. Vaccine, v. 22, p. 2234-2243, 2004.

BRETSCHER, P.A.; OGUNREMI, O.; MENON, J.N. Distinct immunological states in murine cutaneous leishmaniasis by immunizing with different amounts of antigen: the generation of beneficial, potentially harmful, harmful and potentially extremelt harmful states. Behring Institute Mitteilungen, n.98, p. 153-9, 1997.

BRITTINGHAM A., MORRISON C.J., MCMASTER W. R., MCGWIRE B. S., CHANG K., MOSSER D.M.. Role of the Leishmania surface protease gp63 in complement fixation, cell adhesion and resistance to complement-mediated lysis. The Journal of Immunology, 155: 3102-3111.,1995.

CARDI, B.A.; NASCIMENTO, N.; ANDRADE Jr, H.F. Irradiation of Crotalus durissus terrificus crotoxin with 60Co gamma-rays induces its uptake by macrophages through scavenger receptors. International Journal of Radiation Biology, v. 73, n. 5, p. 557-64, 1998.

CARDOSO S.R.; DA SILVA J.C.; DA COSTA R.T.; MAYRINK W.; MELO M.N.; MICHALICK M.S.; LIU I.A.; FUJIWARA R.T.; NASCIMENTO E. Identification and purification of immunogenic proteins from nonliving promastigote polyvalent Leishmania vaccine (Leishvacin ).Revista da Sociedade Brasileira de Medicina Tropical, v. 36, $\mathrm{n}$. 2, p. 193-9, 2003.

CHAPMAN, J.D. Radiation chemical studies with nitrofurazone as related to its mechanism of radiosensitization. Radiation Research, v. 53, n. 2, p. 190-203, 1973.

COURA, J.R. Leishmaniose Tegumentar Americana. In: Dinâmica das Doenças Infecciosas, Ed. Guanabara Koogan, 1ª Edição, p. 706-7, 2005.

COURRET, N., LANG, T., MILON, G., ANTOINE, J. C. Intradermal inoculations of low 
doses of Leishmania major and Leishmania amazonensis metacyclic promastigotes induce different immunoparasitic processes and status of protection in BALB/C mice. International Journal of Parasitology, v. 33, pp. 1373-1383, 2003

CUNNINGHAM, A. Parasitic adaptive mechanisms in infection by Leishmania. Experimental and Molecular Pathology, v. 72, p. 132-141, 2002.

DAS, M.; MUKHERJEE, S.B.; SHAHA, C. Hydrogen Peroxide apoptosis-like death in Leishmania donovani promastigotes. Journal of Cell Science, v. 114, p. 2461-69, 2001.

DAVIS P.H.; STANLEY S.L. Jr. Breaking the species barrier: use of SCID mouse-human chimeras for the study of human infectious diseases. Cell Microbiology, v. 5, n. 12, p. 849-60, Review, 2003.

DAVIES CR, KAYE P, CROFT SL, SUNDAR S. Leishmaniasis; new approaches to disease control. Biochemistry Journal, v.326, p.377-382, 2003.

DE SOUZA, W.; LANFREDI-RANGEL, A.; CAMPANATI, L. Contribution of Microscopy to a Better Knowledge of the Biology of Giardia lamblia. Microscopy and Microanalysis, $v$. 10, p. 513-527, 2004.

DELVES, P.J.; ROITT I.M. The advances in immunology. The New England Journal of Medicine, v. 343, n. 1, p.37-49, 2000.

DOMÍNGUEZ M., MORENO I.,LÓPEZ-TRASCASA M., TORAÑO A. Complement Interaction with Trypanosomatid Promastigotes in Normal Human Serum. Journal of Experimental Medicine, vol. 195, n.4, p. 451-459, 2002.

DUARTE, M.I.S.; MARIANO, O.N.; TAKAKURA, C.F..; UIP, D.E.; CORBETT, C.E.P. A fast method for processing biologic material for electron microscopic diagnosis in infectious disease. Ultraestructural Pathology, v. 16, p. 475-82, 1992. 
EL-GAWISH M.A., MOAWAD M.A. Immunological studies on mice vaccinated with irradiated cercaria and IL-12 against Schistosoma mansoni infection.

Egyptian Journal of Immunology, v.10, n. 2, p. 39-48, 2003.

FIELD, M.C.; ALLEN, C.L.; DHIR, V.; GOULDING, D.; HALL, B.S.; MORGAN, G.W.;VEAZEY, P.; ENGSTLER. M. New Approaches to the Microscopic Imaging of Trypanosoma brucei. Microscopy and Microanalysis, v. 10, p. 621-636, 2004.

FURTADO, T. Advances and perspectives in American cutaneous leishmaniasis. Medicina Cutánea Ibero-Latino-Americana , v. 15, n. 2, p. 105-16, 1987.

GARLAPATI, S., DAHAN, E. and SHAPIRA, M. Effect of acid $p H$ on heat shock gene expression in Leishmania. Molecular and Biochemical Parasitology, v. 100, p. 95-101, 1999.

GOMES S.A.; GRACIANO G.L.; NOGUEIRA N.F.; DE SOUZA W.; GARCIA E.S.; AZAMBUJA P. Effects of gamma irradiation on the development of Trypanosoma rangeli in the vector Rhodnius prolixus. Journal of Invertebrate Pathology, v. 79, n. (2), p. 8692, 2002.

GREENSTOCK, C.L. Redox processes in radiation biology and cancer. Radiation Research, v. 86, n. 2, p. 196-211, 1981.

HALDANE, J.B.S. Possible Worlds. New York: Hugh \& Bros, 1928.

HALL, E.J. Radiobiology for the radiologist, Lippincott Willians \& Wilkins, 2000.

HANSON, W.L.; CHAPMAN, W.L. JR.; WAITS, V.B. Immunization of mice with irradiated Trypanosoma cruzi growth in cell culture: relation of numbers of parasites, immunizing injections, and route of immunization to resistance. International Journal of Parasitology, v. 6, n. 4, p. 341-7, 1976 . 
HAYASHI H.; NARUMI I.; WADA S.; KIKUCHI M.; FURUTA M.; UEHARA K.; WATANABE $\mathrm{H}$. Light dependency of resistance to ionizing radiation in Euglena gracilis. Journal of plant physiology , v. 161, n. 10, p. 1101-6, 2004.

HIRAMOTO, R.M.; GALISTEO JR, A.J.; NASCIMENTO, N.; ANDRADE JR, H.F. 200 Gy sterilized Toxoplasma gondii tachyzoites maintain metabolic functions and mammalian cell invasion, eliciting cellular immunity and cytokine response similar to natural infection in mice, Vaccine, v. 20, p. 2072-2081, 2002.

HRAZDIRA, I.; SKALKA, M. Changes produced by ultrasound in the deoxyribonucleoprotein complex in vitro. Folia Biologica, v. 16, n 2, p. 121-8, 1970.

JANEWAY, C.A.; TRAVERS, P.; WALPORT, M.; CAPRA, J.D. Imunobiologia: O sistema imune na saúde e na doença. São Paulo, S.P.: Artes Médicas, 2000.

JENKINS M.; HIGGINS J.; KNIEL K.; TROUT J.; FAYER R. Protection of calves against cryptosporiosis by oral inoculation with gamma-irradiated Cryptosporidium parvum oocysts. Journal of Parasitology, v. 5, p.1178-80, 2004.

KEMPNER, E.S. Molecular size determination of enzymes by radiation inactivation. Advances in Enzymology and Related Areas of Molecular Biology , v. 61, p. 107-47, 1988.

LAINSON, R.; RYAN, L.; SHAW, J.J. Infective stages of Leishmania in the sandfly vector and some observations on the mechanism of transmission. Memórias do Instituto Oswaldo Cruz, v. 82, n. 3, p. 421-4, 1987.

LAND, K.M. Phosphoglicans and Leishmania. Trends in Immunobiology, v. 8, n. 5, p.211, 2000.

LAURENTI, M.D.; ORIN, A.; SINHORINI, I.L.; CORBETT, C.E. The role of complement in the early phase of Leishmania (Leishmania) amazonensis infection in BALB/c mice.

Brazilian Journal of Medicine and Biology Research, v. 37, n. 3, p. 427-34, 2004. 
LEMESRE J.L,. DARCY F., KWEIDER M., CAPRON A., SANTORO F. Requirements of defined cultivation conditions for standard growth of Leishmania promastigotes in vitro. Acta Tropica, 45(2):99-108, 1988.

LIEW, F.Y.; XU, D.; CHAN, W.L. Immune effector mechanism in parasitic infections. Immunology letters, v. 65, n.1-2, p. 101-04, 1999.

LOHOFF, M.; GESSNER, A.; BOGDAN, C.; ROLLINGHOFF, M. The Th1 and Th2 paradigm and experimental murine leishmaniasis. Allergy Immunology, v. 115, p. 191202, 1998.

MAHALINGAM, S.; KAUPIAH, G. Chemokines and chemokine receptors in infectious disease. Immunology and Cell biology, v.77, p. 469-75, 1999.

MAIOLI, T.U.; TAKANE, E.; ARANTES, R.M.; FIETTO, J.L.; AFONSO, L.C. Immune response induced by New World Leishmania species in C57BL/6 mice. Parasitology Research, v. 94, n. 3, p. 207-12, 2004.

MAHONEY, A.B.; SACKS, D.L.; SARAIVA, E.; MODI, G.; TURCO, S.J. Intra-species and stage-specific polymorphisms in lipophosphoglycan structure control Leishmania donovani-sand fly interactions. Biochemistry, v. 38, n. 31, p. 9813-23, 1999.

MAYRINK, W.; WILLIAMS, P.; COELHO, M.V.; DIAS, M.; MARTINS, A.V.; MAGALHÃES, P.A.; DA COSTA, C.A.; FALCAO, A.R.; MELO, M.N.; FALCÃO, A.L. Epidemiology of dermal leishmaniasis in the Rio Doce Valley, State of Minas Gerais, Brazil. Annals of Tropical Medicine and Parasitology, v, 73, n. 2, p. 123-37, 1979.

MAYRINK, W.; BOTELHO, A.C.; MAGALHAES, P.A.; BATISTA, S.M.; LIMA, A.D.E.O.; GENARO, O.; COSTA, C.A.; MELO, M.N.; MICHALICK, M.S.; WILLIAMS, P.; DIAS, M.; CAIAFFA, W.T.; NASCIMENTO, E.; MACHADO-COELHO, G.L. Immunotherapy, immunochemotherapy and chemotherapy for American cutaneous leishmaniasis treatment. Revista da Sociedade Brasileira de Medicina Tropical, v. 39, n. 1, p. 14-21, 2006. 
MCGWIRE, B.S.; O'CONNELL, W.A.; CHANG, K.P.; ENGMAN, D.M. Extracellular release of the glycosylphosphatidylinositol (GPI)-linked Leishmania surface metalloprotease, gp63, is independent of GPI phospholipolysis: implications for parasite virulence. Journal of Biological Chemistry, v. 277, n. 11, p. 8802-9, 2000.

MORA, A.M.; MAYRINK, W.; DA COSTA, R.T.; DA COSTA, C.A.; GENARO, O.; NASCIMENTO, E. Protection of $c 57 / b /$ mice by vaccination with association purified proteins from Leishmania (Leishmania ) amazonensis. Revista do Instituto de Medicina Tropical de São Paulo, v. 41, n. 4, p. 243-8, 1999.

MORTARA, R.A.; ANDREOLI, W.K., TANIWAKI, N.N.; FERNANDES ,A.B.; SILVA, C.V.; FERNANDES, M.C.; L'ABBATE, C.; SILVA, S. Mammalian cell invasion and intracellular trafficking by Trypanosoma cruzi infective forms. Anais da Academia Brasileira de Ciências, v. 77, n. 1, p. 77-94, 2005.

MUSKUS, C.E., VILLA, M.M. Metaciclogénesis: un processo fundamental em la biología de Leishmania. Biomédica, v.22, p. 167-177, 2002.

NASHED, B.F.; MAEKAWA, Y.; TAKASHIMA, M.; ZHANG, T.; ISHII, K.; DAINICHI, T.; ISHIKAWA, H.; SAKAI, T.; HISAEDA, H.; HIMENO, K. Different cytokines are required for induction and maintenance of the Th2 type response in DBA/2 mice resistant to infection with Leishmania major. Microbes Infection, v. 2, n. 12, p. 1435-43, 2000.

NASCIMENTO, N.; SEEBART, C.S.; FRANCIS, B.; ROGERO, J.R.; KAISER, I.I. Influence of ionizing radiation on crotoxin: biochemical and immunological aspects. Toxicon, v. 34, n. 1, p. 123-131, 1996.

NUNES, A.C.; RAMALHO-PINTO, F.J. Complement resistance of Leishmania amazonensis promastigotes is independent of parasite protease ans lysis of sensitive forms is not due to natural antibodies in normal human serum. Brazilian Journal of Medical and Biological Research, v. 29, p. 1633-1640, 1996.

NUNES, A.C., ALMEIDA-CAMPOS, F.R., HORTA, M.F. E PINTO-RAMALHO, F.J. 
Leishmania amazonensis promastigotes evade complement killing by interfering with the late steps of the cascade. Parasitology. V.115 n. 6, p.601-9, 1997.

OPARIN A.I. Evolution of the concepts of the origin of life, 1924-1974. Origins of Life, v. 7, n. 1, p. 3-8, 1976.

OUELLETTE, M.; OLIVIER, M.; SATO, S.; PAPADOPOULOU, B. Studies on the parasite Leishmania in the post-genomic era. Medicine and Science (Paris), v. 19, n. 10, p. 9009, 2003 .

PETRY, F. Structural Analysis of Cryptosporidium parvum. Microscopy and Microanalysis, v. 10, p. 586-601, 2004.

PINTO-DA-SILVA L.H., CAMURATE M., COSTA K. A., OLIVEIRA S.M.P, CUNHA-ESILVA N.L., SARAIVA E.M.B. Leishmania (Viannia) braziliensis metacyclic promastigotes purified using Bauhinia purpurea lectin are complement resistant and highly infective for macrophages in vitro and hamsters in vivo. International Journal for Parasitology 32 : 1371-1377, 2002.

PINTO, E.F., CORTEZIA, M.M., BERGMAN, B.R. Interferon-gamma-inducing oral vaccination with Leishmania amazonensis antigens protects $B A L B / C$ and $C 57 B L / 6$ mice against cutaneous leishmaniasis. Vaccine, v. 21, p. 3534-3541, 2003.

PIRMEZ, C. Immunophatology of American cutaneous leishmaniasis. Memórias do Instituto Oswaldo Cruz, v. 87, n. 5, p.105-9, 1992.

PROBST, P.; STROMBERG, E.; GHALIB, H.W.; MOZEL, M.; BADARO, R.; REED, G.R.; WEBB, J.R. Identification and characterization of $T$ Cell-Stimulating Antigens from Leishmania by CD4 T Cell expressing cloning. Journal of Immunology, v. 166, n. 1, p. 498-505, 2001.

QUAN F.S., LEE J.B., BAE J.S., OHWATARI N., MIN Y.K., YANG H.M. Resistance to reinfection in rats induced by irradiated metacercariae of Clonorchis sinensis.

Memórias do Instituto Oswaldo Cruz. v. 100, n. 5, p. 549-54, 2005. 
RALTON J.E., MULLIN K.A., MCCONVILLE M.J. Intracellular trafficking of glycosylphosphatidylinositol (GPI)-anchored proteins and free GPIs in Leishmania mexicana. Biochemical Journal, vol.363, p. 365-375, 2002.

RAMAMOORTHY S., LINDSAY D.S., SCHURIG G.G., BOYLE S.M., DUNCAN R.B., VEMULAPALLI R., SRIRANGANATHAN N. Vaccination with gamma-irradiated Neospora caninum tachyzoites protects mice against acute challenge with $\mathrm{N}$. caninum.

Journal of Eukaryotic Microbiology v.53, n. 2, p. 151-6, 2006.

RASCHKE W. C., BAIRD S., RALPH P., NAKOINZ I. Functional macrophage cell lines transformed by Abelson leukemia virus. Cell 15: 261-267, 1978.

BIRGITTA RASMUSSON and ALBERT DESCOTEAUX. Contribution of Electron and Confocal Microscopy in the Study of Leishmania-Macrophage Interactions. Microscopy and Microanalysis, v. 10, p. 656-661, 2004.

REQUENA, J.M.; ALONSO, C.; SOTO, M. Evolutionary conserved proteins as prominent immunogens during Leishmania infections. Parasitology Today, v. 16, n. 6, p. 246-50, 2000.

REY, L. Bases da Parasitologia Médica. Ed. Guanabara-Koogan, $5^{\text {a }}$ ed, Rio de Janeiro, 2002.

RIBEIRO-DE-JESUS, A.; ALMEIDA, R.P.; BACELLAR, H.L.; CARVALHO, E.M.Cytokine profile and pathology in human leishmaniasis. Brazilian Journal of Medical and Biological Research, v. 31, p. 143-48, 1998.

RITTIG, M.G.; BOGDAN,C. Leishmania-Host Cell interaction: Complexities and alternative view. Parasitology Today, v. 16, n. 7, p. 292-7, 2000.

ROGERS, M.E.; CHANCE, M.L.; BATES, P.A. The role of promastigote secretory gel in the origin and transmission of the infective stage of Leishmania mexicana by the sand fly Lutzomyia longipalpis. Parasitology, v. 124, p. 495-507, 2002. 
ROSSI-BERGMANN, B., CORTEZIA, M. M., PINTO, E.F. Interferon-gamma-inducing oral vaccination with Leishmania amazonensis antigens protects $B A L B / C$ and $C 57 B L / 6$ mice against cutaneous leishmaniasis. Vaccine, v.21, pp. 3534-3541, 2003.

SACKS, D.L., MDI, G., ROWTON, E., SPÄTH, G., EPSTEIN, L., TURCO, S.J. And BEVERLEY, S.M. The role of phosphoglycans in Leishmania-Sand fly interactions. Proceedings of National Academy of Science, v. 97, n.1, p. 406-411, 2000.

SARTORI A., OLIVEIRA M. A. P., SCOTT P., TRINCHIERI C. Metacyclogenesis Modulates the Ability of Leishmania Promastigotes to Induce $1 \mathrm{~L}-12$ Production in Human Mononuclear Cells. The journal of Immunology, v. 159, p. 2849-2857, 1997.

SAVANI, E.S.M.; GALATI, E.A.B.; CAMARGO M.C.G.O.; DÚRIA, S.R.; DAMACENO, J.T.; BALDUINO, S.A. Inquérito sorológico sobre leishmaniose tegumentar americana em cães errantes no estado de São Paulo, Brasil. Revista De Saúde Pública, v. 33, n. 6, p. 62931, 1999.

SINGH S, SIVAKUMAR R. Challenges and new discoveries in the treatment of leishmaniasis. Journal of Infection and Chemotherapy, v. 10, n. 6, p. 307-15, Review, 2004

SOARES M.B.P., DAVID J.R., TITUS R.G. An In Vitro Model for Infection with Leishmania major That Mimics the Immune Response in Mice. Infection and Immunity, Vol. 65, No. 7p. 2837-2845, 1997.

SOARES, R.P.; MACEDO , M.E.; ROPERT , C.; GONTIJO , N.F.; ALMEIDA, I.C.; GAZZINELLI, R.T.; PIMENTA, P.F.P.; TURCO, S.J. Leishmania chagasi: lipophosphoglycan characterization and binding to the midgut of the sandfly vector Lutzomyia longipalpis. Molecular \& Biochemical Parasitology, v. 121, P. 213-224, 2002

SOARES, R.P.; TURCO, S.J. Lutzomyia longipalpis (Diptera: Psychodidae: Phlebotominae): a review. Anais da Academia Brasileira de Ciências, v. 75, n. 3, p. 
301-30, Review, 2003.

SONG, C.C.; YUAN, X.Z.; SHEN, L.Y.; GAN, X.X.; DING, J.Z. The effect of cobalt-60 irradiation on the infectivity of Toxoplasma gondii. International Journal of Parasitology, v. 23, n. 1, p. 89-93, 1993.

DE SOUZA LEAO S.; LANG T.; PRINA E.; HELLIO R.; ANTOINE J.C. Intracellular Leishmania amazonensis amastigotes internalize and degrade MHC class II molecules of their host cells. Journal of Cell Science, v. 108, n. 10, p. 3219-31, 1995.

SPÄT, G.F., GARRAWAY, L. A., TURCO, S. J. E BEVERLEY S. M. The role(s) of lipophosphoglycan (LPG) in the establishment of Leishmania major infections in mammalian hosts. Proceedings of National Academy of Science, v. 100, n. 16, p. 9536-9541, 2003.

STRICKLAND, G.T. Infectious of the blood and reticuloendothelial system. Hunter's Tropical Medicine and emerging infectious disease, p. 665-687, 2000.

TANIGUCHI J.E., ARAÚJO H.H., BISUGO M.F.L; CUNHA M.C., ELIAS E.A., LAROSA C.R., A epidemiologia da leishmaniose tegumentar americana no estado de São Paulo, Brasil. II: utilização do antígeno particulado de Leishmania braziliensis em inquérito canino em regiões endêmicas. Revista do Instituto Adolfo Lutz, v.57, n.2, p. 65-71, 1998.

TERABE M, KURAMOCHI T, HATABU T, ITO M, UEYAMA Y, KATAKURA K, KAWAZU S, ONODERA T, MATSUMOTO Y. Non-ulcerative cutaneous lesion in immunodeficient mice with Leishmania amazonensis infection. Parasitology International v. 48, n. 1, p. 47-53, 1998 .

TERABE, M., hATABU, T., TAKAHASHI, H., ITO, M., ONODERA, T., MATSUMOTO, Y. Leishmania amazonensis infection in nude mice. Experimental Animals, v. 48, n. 2, p. 119-123, 1999.

TRISCHMANN, T.M. Susceptibility of radiation chimeras to Trypanosoma cruzi. Infection Immunology, v. 36, n. 2, p. 844-6, 1982. 
ULIANA S.R.; NELSON K.; BEVERLEY S.M.; CAMARGO E.P.; FLOETER-WINTER L.M. Discrimination amongst Leishmania by polymerase chain reaction and hybridization with small subunit ribosomal DNA derived oligonucleotides. The Journal of Eukaryotic Microbiology ., v. 41, n. 4, p. 324-30 1994.

DO VALE E.C.; FURTADO T. Ectopic cutaneous schistosomiasis caused by Schistosoma mansoni. Medicina Cutánea Ibero-Latino-Americana , v.15, n. 3, p. 233-7, 1987 .

VAN HELLEMOND, J.J.; VAN DER MEER, P.; TIELENS, A.G.M. Leishmania infantum promastigotes have a poor capacity for function anaerobic functioning and depend mainly on respiration for their energy generation. Parasitology, v. 114, n. 7, p. 351-360, 1997.

VENKATESAN P.; WAKELIN D. ELISAs for parasitologists: or lies, damned lies and ELISAs. Parasitology Today, v. 9, n. 6, p. 228-32, 1993.

VICKERMAN, K. In: Ciba Symposium, 20 (new series), p. 171-89, 1974.

WILSON, I.B.H.; O’DONELL, N.; ALLEN,S.; MEHLERT, A. Typing of Leishmania phosphoglycans by electrospray mass spectrometry. Molecular and Biochemical Parasitology, v. 100, p. 207-215, 1999.

WORLD HEALTH ORGANIZATION. Program for the surveillance and control of Leishmaniasis, p. 1-3, 2004.

YAO C.; LUO J.; HSIAO C.; DONELSON J.E.; WILSON M.E. Internal and surface subpopulations of the major surface protease (MSP) of Leishmania chagasi. Molecular and Biochemical Parasitology, v. 139, n. 2, p. 173-83, 2005.

ZAKAI H.A.; CHANCE M.L.; BATES P.A. In vitro stimulation of metacyclogenesis in Leishmania braziliensis, L. donovani, L. major and L. mexicana. Parasitology, v. 116, $\mathrm{n}$. 4, p. 305-9, 1998. 